(C) Daniel F. Spulber 2014

\title{
Prices versus Prizes: Patents, Public Policy, and the Market for Inventions
}

\author{
Daniel F. Spulber \\ Northwestern University
}

August 2014

\begin{abstract}
I consider whether government prizes should replace market prices for inventions. The America COMPETES Reauthorization Act of 2010 establishes a framework for government prizes. I examine how the economic benefits of the market for inventions should antitrust and public policy towards patents. I consider the limitations of a prize system in terms of economic efficiency. I find that the deadweight welfare loss argument for replacing market prices with government prizes is flawed. I show how prices in the market for inventions provide state-contingent signals that guide invention, commercialization, innovation, financing, and complementary inventions. I examine how prices in the market for inventions provide indicators of technological change. I conclude that replacing market prices with government prizes would harm invention, innovation and economic growth.
\end{abstract}

JEL Codes: D40, O31, L10

Keywords: Invention, R\&D, competition, innovation, prices, prizes

* Elinor Hobbs Distinguished Professor of International Business, Department of Strategy, Kellogg School of Management, Northwestern University, 2001 Sheridan Road, Evanston, IL, 60208, and Professor of Law (Courtesy), Northwestern University Law School. E-mail: jems@kellogg.northwestern.edu. The opinions expressed in this paper are solely those of the author and not necessarily those of any other individual or organization. This paper is a sequel to an earlier paper on markets for invention. I thank Alexei Alexandrov, Justus Baron, Richard Epstein, Kirti Gupta, Steve Haber, John Howells, Ron Katznelson, Scott Kieff, Zorina Khan, Mark Lemley, Adam Mossoff, Ben Roin, Carl Shapiro, Ralph Siebert, Henry Smith, Mark Snyder, and Richard Taffet for helpful comments on the earlier paper. I am grateful to Qualcomm and the Kellogg School of Management for research support. 


\section{Introduction}

Should government prizes replace market prices for inventions? The America COMPETES Reauthorization Act of 2010 empowers the heads of federal agencies in the Executive branch to create prize competitions. " The Act provides for "voluntary" transfers of technology and licensing of intellectual property (IP) to the government. ${ }^{2}$ The Act allows the use of both tax revenues and private funds to pay cash prizes. ${ }^{3}$ More than just a choice of policy instruments, the Act revives the classical debate between competitive markets and central planning. Patents, along with copyrights, trademarks, trade secrets and other IP, provide the foundation of the market for inventions (Spulber, 2014). In contrast, under the government prize system, central planners design the contests, choose the awards, select the winning inventions, and allocate technologies to producers. ${ }^{4}$ In this paper, I show that market prices clearly dominate government prizes in terms of both static and dynamic economic efficiency. I argue that replacing market prices with government prizes would damage invention, innovation, social welfare, and economic growth.

The standard argument for government prizes replacing market prices is based on a "free lunch". Prize advocates argue that market prices create a deadweight welfare loss and yet at the same time assume that government taxes create no economic distortions.

\footnotetext{
${ }^{1}$ P.L. 111-358, Section 105. The full name of the Act is The America Creating Opportunities to Meaningfully Promote Excellence in Technology, Education, and Science Act. The Act was signed into law by President Barack H. Obama on January 4, 2011. Practically any federal agency in the executive branch can offer prizes including for example the Department of Energy, the Department of Education, the National Aeronautics and Space Administration, and the National Oceanic and Atmospheric Administration.

${ }^{2}$ The Act states that "The Federal Government may not gain an interest in intellectual property developed by a participant in a competition without the written consent of the participant." The Act also allows the government to license IP from inventors: "The Federal Government may negotiate a license for the use of intellectual property developed by a participant for a competition." (P.L. 111-358, Section 105).

3 "Support for a prize competition under this section, including financial support for the design and administration of a prize or funds for a monetary prize purse, may consist of Federal appropriated funds and funds provided by the private sector for such cash prizes." (P.L. 111-358, Section 105).

${ }^{4}$ The Act specifies the elements of prize contests: "the subject of the competition;" "the rules for being eligible to participate in the competition;" "the process for participants to register for the competition;" "the amount of the prize;" and "the basis on which a winner will be selected" (P.L. 111-358, Section 105).
} 
The policy of government subsidies to achieve marginal cost pricing is a return to the marginal cost controversies of public utility regulation, going back at least to Harold Hotelling $(1938) .{ }^{5}$ Ronald Coase $(1946,1947)$ observes that government subsidies to attain marginal cost pricing would result in tax-induced distortions, inefficient resource allocation, income redistribution, and rent seeking. ${ }^{6}$ Coase's objections to subsidized marginal cost pricing apply directly to IP (Duffy, 2004). The administrative costs of government control of invention, innovation, and technology diffusion would be many times market transaction costs. Governments cannot expect to improve static and dynamic efficiency of market allocation of inventions. Government prizes would generate deadweight welfare losses greater than any caused by market prices. Replacing market prices with government prizes would create the very problem they are meant to solve.

Markets offer significant economic advantages over central planning. The efficient performance of markets is fundamental to the history and development of economic thought. The informational attributes of the price system figure prominently in the renewed interest in price theory; see Glen Weyl (2014). As Friedrich Hayek (1945, p. 523) explains, the price system is a "condensed index of relative change." The price system provides communication and coordination: "In abbreviated form, by a kind of symbol, only the most essential information is passed on, and passed on only to those concerned" (Hayek, 1945, p. 526). Prices result from market transactions and serve to guide decentralized decision making by individuals in the market place who have the best knowledge of their own situations.

Yet, central planners cannot hope to make efficient economic decisions because they lack the staggering amount of subjective knowledge that is dispersed among individuals. ${ }^{7}$ Central planners, even if fully informed, need not act in the public interest. Central planners can be expected to suffer from corruption, rent seeking, abuse of power, discrimination, bureaucratic inefficiency, and other forms of government failure. The dramatic differences in the historical performance of market economies and centrallyplanned economies are even more pronounced in innovative industries. The complexities of invention and innovation create information challenges for market participants that are

\footnotetext{
${ }^{5}$ Hotelling (1938) recommends government subsidies to achieve marginal cost pricing for industries with economies of scale such as public utilities.

${ }^{6}$ As Arthur Pigou (1947) points out, the provision of public goods entails both direct costs and indirect costs caused by taxation. See also Browning (1976) and Wildasin (1984).

${ }^{7}$ Hayek (1945, p. 526) observes: "Fundamentally, in a system where the knowledge of the relevant facts is dispersed among many people, prices can act to coordinate the separate actions of different people in the same way as subjective values help the individual to coordinate the parts of his plan."
} 
insurmountable for central planners. I present an economic analysis of prices in the market for inventions and compare with the proposed government prize system.

The main findings are as follows. First, I emphasize that an economically meaningful comparison of prices and prizes at least requires a consistent comparison of allocative efficiency. A system of government prizes would likely reduce allocative efficiency and generate greater deadweight welfare losses that a market. The prize system itself is not intended to provide a public good or to subsidize the provision of a public good. Rather, the government prize system is intended to replace market allocation of inventions with public allocation, so as to eliminate the assumed deadweight welfare loss due to prices. Extensive competition in the market for inventions reduces deadweight welfare loss if any and implies that the monopoly deadweight welfare loss assumption is unrealistic. The government must collect taxes to pay for the prizes, but taxes create their own deadweight welfare losses that are generally ignored by prize advocates. ${ }^{8}$ Markets generally promote efficiency in resource allocation and in contrast, government agencies are not able to achieve efficient resource allocation, often incurring substantial administrative costs and pursuing objectives that are inconsistent with allocative efficiency. Although invention and innovation may exhibit economies of scale, they are not natural monopolies because there are economic benefits from applying a variety of inventions and from continual technological change. In addition, even if technology were a public good, it need not be made available for free; inventions are costly to produce, their market returns are rivalrous, and they generally are provided in abundance by competitive markets. Innovation also is not free; there are positive marginal costs of developing inventions, diffusing technology, and creating innovations.

Second, I examine how prices in the market for inventions are generated by competition and coordination that selects the best inventions and innovations. Competitive pressures among inventors and among producers serve to increase incentives to invent (Spulber, 2013). Inventions and innovations are not exogenous forces but instead are the results of economic decisions and transactions among participants in the market for inventions. Hayek (2002) points out that competition is a discovery procedure because it helps inventors and producers discover the best inventions and innovations. Government prizes require planners to choose the best technology in advance, and forgo the benefits of competition.

Third, I explain how prices in the market for inventions guide economic decisions of inventors, innovators, producers, investors, and consumers. Market prices for inventions market prices convey signals about seller cost and buyer willingness to pay. Market prices for inventions thus promote innovation and competition and increase both static and dynamic efficiencies. Prices are state-contingent because they reflect technological change and the features of complementary and substitute inventions. Prices

\footnotetext{
${ }^{8}$ See Judd (1987) and Feldstein (1999) on estimates of deadweight welfare losses from taxes.
} 
are state-contingent because market forces change prices without the transaction costs of establishing contingent contracts. Prices for inventions therefore guide decision making under uncertainty. The market for inventions is a market for innovative control because ownership of patented inventions not only generates residual returns but allows owners to exercise residual control over the development and application of inventions (Spulber, 2014). Investment in patented inventions occurs both before and after the patent is granted because a patent often covers the initial invention, development of the invention, and innovative applications, as Edmund Kitch (1977) recognized. The state-contingent nature of prices guides the decisions of inventors and innovators in the face of technological uncertainty.

Fourth, I show that market prices for inventions provide highly condensed indicators of complex technological change. Prices for inventions undergo dynamic adjustments that reflect new information, the introduction of new technologies, and anticipation of future discoveries. After a patent is granted, the prices for the relevant inventions fluctuate over time in response to market forces and efforts to develop, commercialize, and apply the inventions. Government prizes are fixed in advance of invention and innovation, so that replacing market prices with government prizes would impede innovation and reduce economic efficiency.

The government prize framework established by the America COMPETES Reauthorization Act of 2010 is a reality. The academic argument for replacing prices with prizes is hardly a straw man. No less an authority than Kenneth Arrow (1962, p. 615), winner of the Nobel Prize in Economic Sciences, ${ }^{9}$ argues in support of government prizes for inventions,

"In an ideal socialist economy, the reward for invention would be completely separated from any charge to the users of the information. In a free enterprise economy, inventive activity is supported by using the invention to create property rights; precisely to the extent that it is successful, there is an underutilization of the information. The property rights may be in the information itself, through patents and similar legal devices, or in the intangible assets of the firm if the information is retained by the firm and used only to increase its profits." 10

Joseph Stiglitz (2006), also a winner of the Nobel Prize in Economic Sciences, clearly states: "Patents are not the only way of stimulating innovation. ... The alternative of awarding prizes would be more efficient and more equitable." Stiglitz (2008, p. 1724) further argues: "The innovation incentives are strong in the patent system, but they are

\footnotetext{
${ }^{9}$ The full name of the prize is the Sveriges Riksbank Prize in Economic Sciences in Memory of Alfred Nobel, http://www.nobelprize.org/nobel prizes/economicsciences/laureates/, Accessed June 10, 2014.

${ }^{10}$ Arrow (1962, p. 615) suggests that the Soviet Union offers an example of such a system of prizes.
} 
distorted, whereas the prize system can provide equivalently strong incentives that are less distorted." 11

Many academics advocate replacing market prices with a system of government prizes. Roin's (2014) useful discussion finds that replacing patents with prizes is the "consensus view", noting that "over the past two decades there has been a virtual explosion of scholarship about prize systems." patents with prizes is extensive. ${ }^{13}$ Standard economic discussions of patents are based on "deadweight welfare loss" arguments (Nordhaus, 1969, 1972, Gallini and Scotchmer, 2002). ${ }^{14}$ Indeed, the idea of government prizes is not new; see Machlup and Penrose (1950) on nineteenth century discussions. Michael Polanvyi (1944, p. 65) states: "In order that inventions may be used freely by all, we must relieve inventors of the necessity

${ }^{11}$ See also Stiglitz (2014).

${ }^{12}$ Roin (2014) observes "The consensus view is that if the government can set prizes that offer equivalent incentives for innovation as intellectual property, it should grant prizes instead of intellectual property because the public would receive the same benefits of innovation without the deadweight loss from higher consumer prices."

${ }^{13}$ Abramowicz (2003, p. 126) states "With a carefully designed prize system, even if an individual decisionmaker makes an error or is influenced by political considerations in calculating a prize, these flaws will not affect the decisions that matter, those made in anticipation of the eventual governmental awards." Kapczynski (2012, p. 996) argues for prizes based on the view that the government should redistribute resources including information ("IP rations access via the price mechanism, and so it distributes resources in a way that is sensitive to the background allocation of resources. Yet the background allocation of resources may be unjust."). Kapczynski and Syed, (2013, p. 1907) also advocate prizes due to deadweight welfare loss but suggest that "prizes can help promote important but highly nonexcludable innovations that would be neglected by the patent system." See also Lichtman (1997), Calandrillo (1998), Barry (2007), and Levmore (2013).

${ }^{14}$ de Latt (1996) considers the choice of prizes and patent duration as a problem of mechanism design under asymmetric information, although applying such a policy would require a different incentive mechanism for every invention. Shavell and van Ypersele (2001) concede that governments may lack the necessary information but argue that government prizes will dominate market prices if there is not too much uncertainty. For some economists, the patent system is a "major wound" that should be abolished (Boldrin and Levin, 2013, p. 18), while leaving in place some government subsidies (Boldrin and Levine, 2008). On replacing patents with government prizes, see also Wright (1983), Kremer (1998), Scotchmer (2004), Gallini and Scotchmer (2002), Hopenhayn et al (2006), and Chari et al. (2012). 
of earning their rewards commercially and must grant them instead the right to be rewarded from the Public purse." 15

I do not argue against either public or private prizes generally; I only address the question of whether government prizes should replace market prices and IP. Both public and private prizes can provide incentives and information that are complementary to the market for inventions. Gary Becker, winner of the Nobel Prize in Economic Sciences, observes the limited patentability of basic discoveries: "To offset the effect of this exclusion from patent protection on the incentive to discover, individuals and governments have created prizes and awards, like the Fields Medal and Nobel Prizes, for mathematical and scientific discoveries." ${ }^{16}$ Weyl and Tirole (2013) provide a general model of market incentives in which public subsidies supplement market prices. Brunt et al. (2012) find that prizes can serve as an inducement to innovation when winners can patent their inventions and indeed find that winning a prize increases patenting. Public and private prizes can achieve various complementary objectives against the backdrop of IP rights, as long as policy makers do not seek to replace IP rights and the market for inventions. ${ }^{17}$ Moser and Nicholas (2013) find historical evidence that prizes provide publicity that encourages patenting and innovation. Murray et al. (2012, p. 1791) find that Grand Innovation Prizes are not substitutes for patents but instead serve such goals as awareness, education, and demonstrating the viability of alternatives.

The paper is organized as follows. Section I considers allocative efficiency and shows that government prizes likely would create deadweight welfare losses far greater than market prices. Section II compares prize competition with price competition. Section III discusses how market prices for inventions provide state-contingent indicators that guide individual technological decisions. Section IV explains how market prices for inventions are condensed indicators of technological change. Section V concludes the discussion.

${ }^{15}$ Emphasis removed. See also Polanyi (1943).

${ }^{16}$ See Gary Becker, “On Reforming the Patent System-Becker,” http://www.beckerposner-blog.com $/ 2013 / 07 /$, ("Narrowing the type of innovations that can be patented is a more challenging task than reducing patent length. The first step is to recognize that many innovations presently cannot be patented. A major example is the inability to patent scientific theories and concepts, such as Einstein's theory of relativity, Darwin's theory of evolution, or Keynes' model of the macro economy. The presumption in excluding basic scientific knowledge from the patent system is that the cost of restricting open access to such discoveries far exceeds any gains in encouraging the development of scientific concepts through granting temporary monopolies to the creators.")

${ }^{17}$ Wei (2007, p. 45) suggests that a "prize system could be used to supplement and close the gaps of both the patent regime and current NIH funding." 


\section{Allocative Efficiency and Deadweight Welfare Loss}

The proposed government prize system is meant to achieve allocative efficiency by replacing market prices with central planning. The purpose of the government prize system for inventions is not to provide a public good. Markets already provide inventions and innovations, so there is no need for a government prize system to replace markets so as to induce invention and innovation. Also, governments already offer significant subsidies for R\&D through grants, procurement, tax credits, and other types of subsidies. Rather, according to advocates, the purpose of the government prize system is to improve efficiency in the allocation of inventions. In this section, I argue that government prizes would likely cause more deadweight welfare loss than competitive markets.

\section{A. Prices versus Prizes}

The standard argument for government prizes replacing market prices is simple enough. ${ }^{18}$ Prize advocates argue that because inventions are public goods they should be priced at $\$ 0$, so that any positive price necessarily creates a deadweight welfare loss. The market price of an invention equals say $\$ 1$, which is necessarily greater than the marginal cost of $\$ 0$. The government would hold a contest, pay the winning inventor a prize of $\$ 1$ or less, take the invention, and make it available to producers at a cost of $\$ 0$ - problem solved! This simple argument is fundamentally flawed because it is based on highly unrealistic assumptions.

The fundamental difference between patents and prizes is that between markets and central planning. With patents, the government establishes general rules of the game through legislation, the courts, and patent grants by the United States Patent and Trademark Office (USPTO), which is part of the executive branch. The market for inventions determines prices for inventions and the selection of the best inventions and innovation. In contrast, with a system of prizes, the government micromanages innovation: it designs the contests, chooses prizes, selects inventions, and allocates technology.

Prize advocates writing in the economics and law literatures generally make a set of inconsistent assumptions about markets and central planning. ${ }^{19}$ These studies effectively assume that governments can achieve greater allocative efficiency than competitive markets. First, prize advocates either understate or ignore the deadweight welfare losses from taxes that would be needed to pay prizes, not to mention the

${ }^{18}$ In his overview of the literature, Roin (2014) observes: "the primary benefit of a prize system has typically been viewed as its ability to avoid the deadweight loss associated with patents."

${ }^{19}$ For example, Kremer (1998, p. 1137) asserts that because of deadweight welfare loss, "competitive markets do not provide appropriate incentives for the production of ideas." Kremer recommends that the government purchase patented inventions using auctions and make them commonly available. 
administrative costs of the prize system. ${ }^{20}$ Prize advocates then assume incorrectly that IP creates economic monopolies, so that any IP owner prices at a monopoly price, which creates monopoly deadweight welfare losses.

Second, prize advocates assume that the government would expend no resources in managing contests, selecting winners, and allocating inventions, thus ignoring administrative costs of prize systems. Prize advocates further ignore the private resource costs of developing inventions, commercializing IP and creating innovations, which is implicit in the assumption that the optimal price of inventions should be zero.

Third, prize advocates assume that the government would be able to achieve economic efficiency in designing contests, selecting winning inventions, and allocating inventions to potential adopters. This assumes that governments maximize social welfare and are fully informed about inventions, market demand, and producer costs. At the same time, prize advocates assume that competitive markets do not achieve allocative efficiency in invention and innovation.

Together these assumptions imply that the government prize system works efficiently and without costs - a free lunch. For example, Kremer (1998, p. 1140) assumes that inventors are monopolists making huge profits while government taxes are chosen optimally by a welfare-maximizing central planner. In practice, taxes differ from optimal taxes but even optimal taxes can generate deadweight welfare losses. ${ }^{21}$ Shavell and van Ypersele (2001) assume that patent owners make monopoly profits and that there are no social costs of taxation. Chari et al. (2012) also assume that patent ownership causes a monopoly deadweight welfare loss. Chari et al. (2012, p. 787) further assume that "Since a prize is a lump sum transfer financed by lump sum taxes on consumers, it does not affect the social surplus." In their setting, prices may yet be optimal because patent owners have private information.

The theoretical comparison between prices and prizes changes if we treat the two alternatives consistently. If both patent owners and governments can use lump-sum transfers, prices are efficient and there is no need for prizes to replace prices. If both patent owners and governments rely on per-unit prices or taxes, there is no a priori advantage of prizes over prices. Suppose for example that the government finances the prize by taxing the good that depends on innovation, so that the cost to consumers is

${ }^{20}$ An exception is de Latt's (1996) model in which price distortions can be less than monopoly levels and government taxes have social costs.

${ }^{21}$ Kremer (1998, p. 1140) states "To see that financing research with monopoly profits not only is not first best, but is generically less efficient than financing research through tax revenue, consider the problem of a social planner choosing a tax to finance research. The principles of Ramsey taxation should clearly guide the planner's decision, and it is highly unlikely that the optimal tax will be a several thousand percent tax on the patented good. Yet financing research by giving monopoly rights to inventors is equivalent to such a tax." 
either a price $p$ with market pricing or the sum of the per-unit tax $g$ and the unit cost $c$ under the new technology with government prizes. Consider the tax rate that would provide a prize that is equivalent to market returns, whether or not the market price is a monopoly price. To provide the equivalent prize, the per-unit tax would need to equal the market price minus the unit cost under the new technology, $g=p-c$. The welfare distortions are equivalent and prizes would have no advantage over prices. Taxing some other activities such as labor can generate other levels of deadweight welfare loss, which are likely to exceed market distortions as the next section will show.

\section{B. Deadweight Welfare Loss: Prices versus Taxes}

Consider the assumption that a government prize system creates no deadweight welfare loss in comparison to the assumption that markets create the maximum monopoly deadweight welfare loss. To put things in perspective, it should be noted that deadweight welfare losses are second-order effects. Any loss in consumers' surplus due to prices exceeding unit costs includes transfers from buyers to sellers that are not counted in deadweight welfare losses. The deadweight welfare losses from market prices are only a small fraction of the returns to inventors because most of the returns to inventors are transfers. $^{22}$

In practice, IP owners do not have economic monopolies. There is extensive competition in the market for inventions, involving both rivalries from substitute and complementary technologies. There are over two million active patents, with more than a quarter million new patents every year. Patent owners face competition from past inventions and entry of new inventions. There is also competition in innovations that use patented inventions and other technologies in products, production processes and transaction methods. Economic returns provide incentives for entry of new inventions and innovations, leading to technological change. These market forces constrain the returns to inventors and innovators thus limiting deadweight welfare losses.

Conversely, taxes generate deadweight welfare losses whether applied to goods and services or labor income. Feldstein (1999, p. 679) estimates "that the deadweight loss per dollar of revenue of using a labor income tax rather than a lump-sum tax is more than twelve times as large as Harberger's classic estimate. If the existing Social Security tax and benefit structure is taken into account, the deadweight loss per dollar of personal income tax revenue is even greater." Feldstein (1999, p. 679) further observes "The analysis implies that a marginal increase in tax revenue achieved by a proportional rise in all personal income tax rates involves a deadweight loss of two dollars per incremental dollar of revenue."

${ }^{22}$ This alleged deadweight welfare loss from positive prices for inventions corresponds to the change in consumer surplus measured by Harberger's $(1964,1971)$ triangle. On the extensive literature on measurement of deadweight welfare loss, including deadweight welfare loss from government taxation, see Diewert (1981). 
The deadweight welfare losses associated with tax increases would certainly offset any reductions in deadweight welfare losses from market prices for inventions. Given Feldstein's (1999) estimates the deadweight welfare losses from taxation would likely exceed any deadweight welfare losses from market prices for inventions. A government prize system would not only raise revenues equal to deadweight welfare losses from prices for inventions but would also need to cover the costs of transfers from technology users to patent owners that are included in the revenues of IP owners. This would require additional tax revenues with additional deadweight welfare losses, suggesting that the economic distortions from government taxes could significantly exceed distortions from market prices. In addition, the government would incur costs of administering a prize system that would require additional tax revenues and associated deadweight welfare losses.

\section{Transaction Costs: Markets versus Central Planning}

Prize advocates tend to assume that transaction costs are zero in markets for invention and innovation. Prize advocates then suggest that because inventions are nonrivalrous, there is no need for price rationing so that the efficient price equals zero. This would suggest that central planners face no problems of calculating "shadow prices" because they already know that the efficient price is zero. However, because the efficient price of an invention need not equal zero, central planners would encounter problems of information gathering and processing in determining "shadow prices".

Market prices for inventions need not equal zero because they must cover transaction costs. The efficient price of an invention generally does not equal zero. This contradicts the notion that any positive price for IP generates deadweight welfare losses. Because the efficient price of an invention can be positive, observation of positive prices in the market for inventions does not indicate economic inefficiency.

Inventions should not be viewed as ideal public goods with zero costs of distribution. Even if inventions are non-rivalrous in terms multiple users, there are economic costs of developing, commercializing, distributing, and applying inventions. It is necessary to ration access to inventions because of the resource costs of providing inventions to potential adopters. A positive price for an invention may simply be due to the economic costs of providing inventions.

Markets for all types of goods and services are subject to such standard transaction costs as search, communication, negotiation, contracting, moral hazard and adverse selection (Spulber, 1999). Markets for inventions are subject to additional transaction costs (Zeckhauser, 1996, Spulber, 2014). Patent owners who commercialize their inventions expend resources searching for potential licensees and negotiating licensing agreements. Inventors also expend resources in developing and demonstrating their inventions. Inventors may need to invest in codifying and transmitting tacit knowledge that is essential for producers to apply their inventions (Spulber, 2012). IP 
owners also devote effort to developing industry standards by participating in standards organizations and industry consortia, which further promotes the diffusion and application of new technologies.

Marketing and sales activities are important because they serve to diffuse inventions and innovations in the economy. Marketing and sales of inventions communicate information to potential buyers and coordinate adoption decisions. The scientific and technological complexities of many inventions suggest that inventions might not diffuse without marketing and sales efforts. Inventions are by their very nature novel and unknown to potential adopters, which can require additional services that are bundled technology transfers. Constraining prices for inventions would result in reduction of marketing and sales activities, which could then reduce diffusion of those technologies, thus generating welfare losses.

This argument for positive prices for inventions is closely related to the arguments for resale price maintenance (Telser, 1960). Resale price maintenance by manufacturers may be needed to make sure that retailers that provide customer services are not undercut by retailers that do not provide customer services. In some markets customer services may be needed to maintain customer demand for products, particularly for new products or technically complex products whose features are not well understood by customers.

Even if usage of inventions is non-rivalrous, the application of inventions to create economic innovations is rivalrous. Users of inventions dissipate economic rents to innovation when they compete in product markets. Innovation is a costly activity, so that users of inventions invest costly resources in applying inventions in new products, production processes and transaction methods. Price rationing and allocation of inventions is useful in providing incentives for the development of invents, investment in innovation, and investment in complementary assets. F. Scott Kieff (2001) emphasizes that common ownership of technology leads to the "tragedy of the commons," overuse that dissipates the value of the invention just as overuse dissipates other types of resources.

Prize advocates also tend to assume that the government would expend no resources in administering the prize system, including managing contests, selecting winners, and allocating inventions. The costs of designing contests, selecting winners, and allocating inventions would be many times the costs of administering the current patent system. ${ }^{23}$ There are over a quarter of a million patents granted per year for highly diverse inventions. The government could not replace the entire patent system with contests and awards in every area of science and technology covered by the patent system without incurring astronomical administrative costs. This suggests that the government

\footnotetext{
${ }^{23}$ The costs of administering the USPTO is approximately $\$ 2.5$ billion per year, http://www.uspto.gov/about/stratplan/ar/USPTOFY2013PAR.pdf
} 
would only offer a handful of prizes. It should be noted that private prize systems also offer few prizes. ${ }^{24}$

The private returns to IP in the economy exceed hundreds of billions of dollars. Monetary prizes for inventors would be financed from general taxation, which would face considerable resistance by taxpayers. The high cost of rewarding inventors and innovators would be a prohibitive amount in comparison to the existing budget of the US federal government. The administrative costs of additional tax collection to finance hundreds of billions of dollars in tax increases would need to be included in the administrative costs of managing the prize system. This again suggests that the government would only be able to offer a few prizes.

Love and Hubbard (2007) propose a fixed prize fund that would be divided equally among innovators who would be compelled to surrender their IP rights. ThenCongressman Bernard Sanders of Vermont, a self-described "democratic socialist", introduced a bill based on their proposal (The Medical Innovation Prize Fund Act, H.R. 417,109 th Congress, 2005). The prize fund would total $0.5 \%$ of GDP. The prize system proposed by the Act would be mandatory, difficult to enforce, and subject to political pressures and industry rent-seeking (Abramowitz, 2003, Wei, 2007). The surrender of IP rights under the later America COMPETES Reauthorization Act of 2010 is voluntary but presumably can be made compulsory as a condition of participation in contests.

Historical experience with a national prize system is instructive. Beginning in the late 1950s, the Soviet Union instituted a system of "inventors' certificates" that involved transfer of the invention to state ownership and some limited monetary and non-monetary rewards for the inventor based on usage (Blair, 1973, Maggs, 1990). Compared to patent systems in market economies during the same time period, it is apparent that this approach was not successful in generative innovation (Maggs, 1990). In addition, the Soviet Union offered a limited honorary "prize" system. During its entire existence, the Soviet Union awarded its "Honoured Inventor of the USSR" medal only sixteen times. ${ }^{25}$

Even with a limited number of government contests, the administrative costs would be significant. Government officials would need to determine what types of inventions should receive "prizes" before discoveries are made. This would require

${ }^{24}$ Private groups such as the $\mathrm{X}$ Prize Foundation also offer prizes for inventors. These prizes generate tournaments in which inventors compete to offer the best invention that satisfies the rules of the competition. Such contests offer relatively few awards in only a small number of topic areas in comparison with the US patent system.

${ }^{25}$ The medal was awarded from 1983 to 1991; "The Presidium of the Supreme Soviet of the USSR was the main conferring authority of the award based on recommendations from the State Committee for Inventions and Discoveries of the USSR and the Central Council of the All-Union Society of Inventors and Innovators," http://en.wikipedia.org/wiki/Honoured_Inventor_of the USSR, Accessed March 29, 2014). 
government officials to have foresight exceeding the combination of all scientists, engineers and other researchers. Government officials also would need to determine what types of inventions were needed by consumers and firms. As Friedrich Hayek emphasizes, this would depend on the impossible requirement that government officials' knowledge of the needs of individuals would equal individual's own knowledge of their needs. The government would also need to know how much to reward inventors, again requiring knowledge of inventions before the fact, knowledge of inventors' costs and scientific opportunities, and knowledge of private benefits from inventions.

\section{Allocative Efficiency: Markets versus Central Planning}

Prize advocates assume that central planners would able to achieve greater allocative efficiency than competitive markets for inventions and innovation. Governments are likely to provide rewards to cronies of politicians, lobbyists, political donors, or ideological allies. A government prize system would encourage rent seeking to obtain prizes, diverting resources away from invention and innovation and toward political influence. Government agencies also are likely to pursue objectives other than allocative efficiency, such as subsidies for groups of voters, increases in employment, income redistribution, regional economic growth, industrial policy, and support for political causes.

There already is a government system for transferring technology in government

labs to the private sector. ${ }^{26}$ This system would need to be expanded to accommodate technology generated by prize competitions. Such an expansion would require additional administrative costs, which would require additional tax revenues and economic distortions. Another concern with such large-scale administrative systems for government prizes and public technology transfers is that they are costly to dismantle, often taking on a life of their own. The effects on markets for inventions could be very difficult to reverse, causing long-term damage to markets for invention. ${ }^{27}$

A government prize system would diminish private incentives for commercialization of inventions. Kieff's (2001) emphasizes the importance of markets in stimulating commercialization of inventions. Public ownership or common ownership of inventions would eliminate private incentives for the commercialization of inventions, as Kieff (2001) explains (see also Abramowicz, 2003). Common ownership of inventions

\footnotetext{
${ }^{26}$ Technology transfers under the Stevenson-Wydler Technology Innovation Act of 1980 (P.L. 96-480) are carried out by the Office of Research and Technology Applications (ORTA). The Stevenson-Wydler Act was amended by the United States Federal Technology Transfer Act of 1986 (P.L. 99-502) and the America COMPETES Reauthorization Act of 2010.

27 Kremer and Williams (2010, p. 11) point out that "Mandatory mechanisms for encouraging innovation cannot be costlessly turned on and off because of the dynamic element inherent in any market in which firms make long-term R\&D investments."
} 
also would diminish incentives for innovation to develop products, manufacturing processes, and transaction techniques based on those inventions. Additionally, common ownership would diminish marketing of products that embody inventions.

Some prize advocates of prizes view the discouragement of commercialization as an advantage of a prize system. For example, Love and Hubbard (2007, p. 1554) assert that marketing products is a "waste,"

The elimination of marketing monopolies, the de-coupling of R\&D incentives from prices, and the creation of an evidence-based reward system linked to changes in health outcomes will lead to significant reductions in expenditures to market products, the area of the largest waste in the current system.

Contrary to this assertion, marketing and sales are important coordination mechanisms in a market economy.

Government agencies would replace decentralized markets with centralized allocation. Government agencies are not well equipped to run market places, consider the high administrative costs and economic distortions that have accompanied experiments with government allocation of goods and services. The transaction costs of government allocation of goods and services are illustrated by the Patient Protection and Affordable Care Act. $^{28}$ According to the US Government Accountability Office, the HEALTHCARE.GOV website was established at an initial cost of $\$ 840$ million and was subject to significant cost overruns and performance failures. ${ }^{29}$ Economic projections suggest that the Act will generate high levels of allocative inefficiency. ${ }^{30}$

Government prizes for inventors would fail to fulfill the functions of IP in product markets. Markets determine the value of goods and services through interaction of supply and demand, and the same applies to inventions. John Stuart Mill (1848, p. 932) explains

${ }^{28}$ See U.S. House of Representatives (2013) and Anderson (2014, p. 10) ("The ACA has thus far added 109 distinct regulations. The time and effort to comply with these rules and regulations will equal an estimated 190 million hours of paperwork per year imposed on business and the health care industry. Most of the estimated 13,000 pages of regulations are focused on health care institutions, and compliance with these rules will also reduce the time spent on direct patient care.")

${ }^{29}$ Statement of William T. Woods, Healthcare.gov Contract Planning and Oversight Practices were Ineffective Given the Challenges and Risks, US Government Accountability Office, July 21, 2014, http://docs.house.gov/meetings/IF/IF02/20140731/102587/HHRG-113-IF02-WstateWoodsW-20140731.pdf. See also "HEALTHCARE.GOV: Ineffective Planning and Oversight Practices Underscore the Need for Improved Contract Management," GAO-14694, July 30, 2014, http://www.gao.gov/assets/670/665179.pdf.

${ }^{30}$ Anderson (2014, p. 2) ("With the new demand for medical services for the millions who are expected to enroll in Medicaid and the federal and state insurance exchanges, the workforce shortages could become catastrophic.") 
this clearly: "the reward conferred by it depends upon the invention's being found useful, and the greater the usefulness, the greater the reward; and because it is paid by the very persons to whom the service is rendered, the consumers of the commodity."

A prize system without property rights for inventors would eliminate the allocative and dynamic efficiencies of the market for inventions. Inventors would lose innovative control over their inventions, thus eliminating incentives to allocate inventions to the highest-value uses. Lack of innovative control would eliminate incentives to continually develop inventions, to commercialize inventions, to introduce innovations based on inventions and to invest in complementary assets.

The prize system lacks all of the key features of the patent system - exclusion, transferability, disclosure, certification, standardization, and divisibility. Without these fundamental elements a market for inventions would be highly constrained and less efficient. Harold Demsetz (1969) identifies IP rights as critical for reducing transaction costs in markets for invention. Richard Epstein (2010) emphasizes the importance of IP property rights in disseminating protected information.

Replacing patents with prizes would be analogous to replacing corporate securities with prizes for investors. Such investment prizes would not finance corporations because they would provide neither return of principle nor return on principle. Invention prizes would not stimulate invention and innovation because they would not provide economic returns for inventors, innovators or investors in complementary assets. Just as investment prizes could not replace financial markets, so invention prizes cannot replace the market for inventions.

Prize systems generally involve either public ownership or common ownership of inventions. With public ownership, the government would presumably make the inventions available to producers without cost, so that the outcome would be the same as with common ownership. With public ownership of inventions, government officials would need to invest in commercializing inventions or developing innovations that apply the prize-winning inventions. This would involve public expenditures for the costs of commercialization and innovation, effectively putting public agencies in the innovation business. Involving public agencies in commercialization and innovation would require public agencies to develop business expertise that is already available in the private sector.

Public commercialization and innovation would generate insurmountable problems of economic planning. Exercising command and control over economic activity has led to significant problems in socialist economies. The collapse of socialist economies such as the Soviet Union provides sufficient evidence that even the operation of traditional technologies by governments is not feasible. The diffusion of new

${ }^{31}$ This is quoted in Machlup and Penrose (1950). 
technologies and management of innovation generally are beyond the scope of government administration.

Governments are not very good at commercializing and diffusing inventions. The failure of government diffusion of technology is illustrated by the major benefits that resulted from the Bayh-Dole Act. The Bayh-Dole Act offers a natural experiment illustrating how markets diffuse innovations and governments do not. The U.S. government provides research grants to universities, non-profit organizations, and small businesses. However, the incentives for invention provided by such grants are accompanied by markets for invention, which provide additional incentives for commercialization and innovation. This was recognized by the Bayh-Dole Act, which permits organizations that receive federal government funding to own inventions rather than transferring ownership to the government. ${ }^{32}$

Prior to the Bayh-Dole Act, government ownership of inventions resulted in minimal commercialization or diffusion of innovations. About $5 \%$ of the 28,000 patents owned by the government were commercialized, and private ownership in contrast generated significant commercializing of inventions though patent licensing by universities. $^{33}$ In the first 25 years following the Act, university patent licensing generated 4,350 new products and 6,000 new firms (Bayh et al., 2009, p. 3). The BayhDole Act resulted in high levels of entrepreneurship by scientists and spurred the rise of university technology transfer offices (TTOs) (see Aldridge and Audretsch, 2011, and the references therein). ${ }^{34}$ According to the Association of University Technology Managers reports that there were about 40,000 active technology licenses and options in 2012 (AUTM, 2013).

Government subsidies are not close substitutes for market incentives for innovation. The National Science Board (2014) estimates that federal agencies provided over $\$ 132$ billion for R\&D. Wright et al. (2014, p. 298) find that even though corporations provide just over $5 \%$ of US university research funding, "corporatesponsored research is surprisingly valuable for further innovation. Data collected over 20 years at nine campuses and three national laboratories administered by the University of California show that corporate-sponsored inventions are licensed and cited more often than federally sponsored ones."

Historical evidence casts doubt on prizes systems as sources of invention and innovation. According to Khan (2014a) "the historical record shows that administered prize systems tend to be associated with the potential for bias or corruption, unpredictable

${ }^{32}$ University and Small Business Patent Procedures Act, 1980, 35 U.S.C. § 200-212, 37 C.F.R. 401.

${ }^{33}$ Council On Governmental Relations, The Bayh-Dole Act: A Guide to the Law and Implementing Regulations 1-2 (1999), http://www.cogr.edu/docs/Bayh_Dole.pdf, cited by McDonough (2006, p. 199).

${ }^{34}$ See also Siegel et al. (2007) and Grimaldi et al. (2011). 
methods of allocation and outcomes, as well as other deficiencies attendant on a nonmarket orientation." Khan (2011) studies inventors in Britain and the U.S. during the transition from the First to the Second Industrial Revolutions and finds that because prizes are less systematic than patents, they offer lower expected benefits for inventors. Khan (2013a) considers a sample of exhibits and premiums at U.S. industrial fairs between 1837 and 1874 and finds that prize winners tended to belong to privileged social groups, with prizes awarded less systematically than patents and unrelated to various proxies for the productivity of the innovation. ${ }^{35}$

Khan (2014c) provides a critically important historical comparison of the effects of patents and prizes on technology diffusion. She compares patented inventions with inventions that were submitted for prizes at annual industrial fairs of the American Institute of New York in the $19^{\text {th }}$ century. Khan finds that patents promote much greater spatial diffusion of innovations than prizes. Additionally, Khan's research shows that patents had large and significant effects on unpatented innovations in contiguous and adjacent counties, in contrast to limited geographic effects of prize-winning inventions.

\section{E. Marginal Cost Prices and Central Planning}

The deadweight welfare loss argument made by prize advocates presumes that inventions should be priced at a marginal cost price equal to zero. The proposed prize mechanism requires the government to subsidize inventions. The government would take inventions and make them available at a zero price to attain the desired marginal cost price.

The prize mechanism proposals are a revival of the natural monopoly argument for government regulation of public utilities. This flawed argument goes back to the old marginal cost controversy (Hotelling, 1938). ${ }^{36}$ Whenever a firm operates at an output where there are economies of scale in production, marginal cost pricing will not generate sufficient revenues to cover costs. Hotelling (1938) and others recommend government subsidies to make up the difference between marginal and average costs.

Public policies such as government regulation should not be based on the existence of economies of scale. This is because practically any economic activity involves economies of scale. Insisting on government ownership or subsidies whenever economies of scale exist would require abandonment of a market economy entirely because economies of scale are pervasive in manufacturing, services, or distribution. Markets routinely allocate goods and services whose production and distribution features economies of scale.

When there are economies of scale, market returns necessarily cover the average costs of production so that firms are able to break even. In competitive markets, prices

\footnotetext{
${ }^{35}$ See also Khan (2014b).

${ }^{36}$ Dupuit (1844) did not recommend either public subsidies or marginal cost pricing, see Ekelund (1968).
} 
tend toward average costs so that the revenues are sufficient to cover costs. Even in markets with few firms, entry and potential competition for the market drive prices toward average costs (Demsetz, 1968, Baumol et al., 1988, Spulber, 1989).

The notion that prices of goods and services should equal marginal costs of production is itself questionable. The optimality of marginal cost pricing depends on various assumptions including a partial equilibrium optimum for a single market and an absence of economies of scale. With economies of scale, the theoretical ideal of a marginal cost pricing equilibrium that is Pareto optimal is likely to be a vacuous concept. This means that a market equilibrium solution may not exist for a general equilibrium model with economies of scale and marginal cost pricing, see Spulber (1989, ch. 8).

In practice however, markets routinely address economies of scale with various pricing mechanisms. Prices can approach marginal pricing when necessary with two-part tariffs and other pricing mechanisms (Spulber, 1989). ${ }^{37}$ A two-part tariff involves a fixed fee that helps to cover fixed costs while allowing firms to lower per-unit fees. It should be emphasized that patent licensing often features two-part tariffs with an up-front lumpsum royalty and a royalty per-unit of output produced using the invention. Royalties can be based on the number of units sold or revenues from sales. ${ }^{38}$ Markets also distribute some products such as broadcast television and Internet search using advertising revenues. Products such as cable television rely on combinations of access fees and advertising revenues. Markets for patents and other IP thus have pricing mechanisms that address efficiency without the need for government ownership or price regulation.

Even if the optimal price is close to marginal cost that does not imply that such a price can be chosen by regulatory authorities. Market forces including competition among buyers and among sellers may drive prices closer to marginal costs evaluated at market equilibrium outputs. This is very different to having regulatory agencies or courts engage in "marginal cost pricing." This would require regulatory agencies or courts to estimate the marginal cost schedule of a firm, to estimate market demand schedule at various prices for the product in question, and then to determine the appropriate output level at which to evaluate both marginal costs and market demand. Then, the regulatory agencies or courts would need to calculate the marginal cost price at this critical output level and then to adjust such a price as costs and demand change over time. Such difficult calculations would need to be repeated across many goods and services.

The calculation of regulated prices created prohibitive administrative costs in natural gas production, railroad rates, and other regulated industries. The regulatory agencies had to calculate so many prices that the time needed to complete the task was

${ }^{37}$ See also Kieff (2001) on market pricing of inventions. Roin (2014) also points out that two-part tariffs for inventions remove some of the theoretical advantages of "prizes."

${ }^{38}$ On the difference between per-unit royalty rates (based on the apportionment rule) and ad-valorem royalty rates (based on the entire market value rule), see Llobet and Padilla (2014) 
nearly limitless (Spulber, 1989). The costs to regulatory agencies of calculating prices of various types of IP also would pose significant administrative challenges, made all the more difficult by the complexities and uncertainties of technological change.

Centrally planned economies faced an even greater challenge. Some economists believed that if only central planners could perform the necessary economic calculations they could derive market prices. The prices would be obtained by maximizing social welfare subject to various resource and production constraints, thus yielding estimates of "shadow prices." For example, Kornai and Lipták (1965) applied mathematical programming to suggest methods of central planning in Hungary and other socialist economies. ${ }^{39}$ Lange (1936-1937, 1945-1946) and Taylor (1929) suggested that by using "shadow prices" central planners would not need to solve millions of equations (Dore and Kaser, 1984). Economists in centrally-planned economies recognized the additional complications that would result for technological change (Lange, 1943). Abba Lerner (1977) also advocated marginal cost pricing as optimal in planned socialist economies.

If only central planners could find the right "shadow prices", they could replace the market. The premise is unlikely; if only pigs could fly. "Shadow prices" set by central planners cannot approach the result of many individual transactions in competitive markets. Central planners not only cannot expect to replicate markets with mathematical programming problems but also cannot access the detailed information that market participants have about their own situation, as Hayek emphasized. The advantages of markets over central planning can be readily observed by comparing economic growth in the market economies in the United States, Europe, and Asia with the economic collapse of centrally-planned economies in Eastern Europe and the Soviet Union. The beneficial effects of introducing market institutions in centrally planned economics are exemplified by the economic transformation of the People's Republic of China.

Prize advocates believe that "shadow pricing" of inventions is feasible because the marginal cost is zero and therefore already known. This relieves central planners of the problem of gathering information about supply and demand and the burden of calculating "shadow prices". However, as will be seen shortly, the marginal cost of inventions is not zero and just as difficult to estimate by central planners as the costs of other goods and services. Calculating government prizes for inventions face at least the same difficulties as calculating "shadow prices" for other types of goods and services, and perhaps even greater problems as a result of scientific and technological uncertainties.

${ }^{39}$ Kornai and Lipták (1965, p. 168) ("The National Planning Bureau wishes to make use of this method too, to obtain sounder foundations for long-term macroeconomic plans.") 40 “'I've a right to think' said Alice sharply, for she was beginning to feel a little worried. 'Just about as much right,' said the Duchess, 'as pigs have to fly ..."' Lewis Carroll, Alice in Wonderland, Chapter 9. 
A government prize system requires central planners to design contests for inventors. Even if central planners could accurately identify a particular category of invention, central planners would need to determine what inventions should be rewarded before discoveries are made, requiring the ability to predict scientific and technological inventions before they occur. Not only would central planners lack the scientific and technological expertise, the problem is impracticable because inventors generally do not know the outcome of $R \& D$ in advance. $R \& D$ not only involves risky outcomes, it involves situations in which the researcher does not know the relative likelihood of possible outcomes and may not be able to describe fully the set of possible outcomes. ${ }^{41}$ In contrast, market prices for patented inventions are established after inventors make the initial discoveries.

\section{Market Competition versus Government Contests}

Competition in markets differs substantially from stylized models of R\&D tournaments and patent races. Prize advocates compare the reward from a prize with the reward from a market price as mechanisms for inducing $\mathrm{R} \& \mathrm{D}$ effort. This comparison is misleading because it fails to take into account the complexity of market competition. In contrast to prize contests, inventions do not just compete for the market, they compete within the market. In contrast to prize contests, market competition is a dynamic process that responds to new discoveries and new information about consumer preferences and producer costs.

\section{A. Competition: Markets versus Tournaments}

In economic models of tournaments, a principal designs the R\&D tournament by offering a contract to multiple agents. ${ }^{42}$ The agents compete by investing in R\&D. The principal offers a prize that is contingent on winning the $R \& D$ tournament based on a specific measure of quality. A researcher wins the prize by beating other researchers according to the quality criterion. Economic models of contests consider the problem of inducing inventors to devote effort to R\&D. Even with an optimally designed contest, agents may choose inefficient effort levels. Baye and Hoppe (2003) show that R\&D efforts in R\&D tournaments are excessive relative to socially optimal effort levels.

\footnotetext{
${ }^{41}$ See Knight (1921) on uncertainty.

42 See Lazear and Rosen (1981), Nalebuff and Stiglitz (1983), Schleifer (1985), Taylor (1995), Fullerton and McAfee (1999), Moldovanu and Sela (2001), Che and Gale (2003), and Riis (2010). Moldovanu and Sela (2001) examine the optimal number of prizes that should be awarded for a single tournament.
} 
In models of $R \& D$ racing, inventors compete by investing in $R \& D$ with the winner being the inventor who makes the discovery first. ${ }^{43}$ The outcome of R\&D is the same for all $R \& D$ projects, with the only difference being the time it takes to make the invention. Baye and Hoppe (2003) show that models of R\&D tournaments and patent races are formally equivalent. ${ }^{44}$

Competition in the market for inventions differs from government contests in many different ways. First, competition in the market for inventions is dynamic. Inventors that engage in $R \& D$ take into account existing inventions developed from past R\&D. Inventors also recognize that after their inventions are introduced, they will face competition from future inventions. This continual interaction and competition among inventions over time is very different from a one-shot tournament.

Second, because competition in the market for inventions is dynamic, there is no simple ranking of inventions based on fixed quality criteria as might occur in a single tournament. There may be some quality rankings among specific groups of inventions at any date, but the quality criteria keep changing as new discoveries are made and as the features of inventions change over time. The prices of inventions change continually in response to the introduction of new inventions, in contrast to the one-time prize in a tournament.

Third, in contrast to tournaments, market competition generally involves many different inventions that are imperfect substitutes in demand. Instead of a single winner of a tournament or an $R \& D$ race, inventions compete in the market by satisfying different needs of diverse producers and consumers. For example, there may be competition among different inventions that reduce the costs of production, but many of these inventions will be purchased in the market because of the different needs of producers. There may be competition among different types of medicines or medical devices without there being a single winner because of the different needs of patients. Each invention may best satisfy the needs of a segment of the market.

Fourth, in contrast to tournaments, market competition involves assembling complementary inventions. Market prices provide coordination devices that help producers to assemble groups of inventions and other complementary resources to create innovations. These innovations may be new production processes, final products, or transaction technologies. This contrasts with government contests that attempt to view inventions in isolation, somehow determining which invention in the winner. What may make a technology useful in the market is how well it interoperates with other inventions and resources. For example, an advance in computer hardware may increase the value of a particular software invention. Without knowing about the computer hardware invention,

${ }^{43}$ For models of patent racing, see Dasgupta and Stiglitz (1980) and Reinganum (1981, 1982, 1989).

${ }^{44}$ Baye and Hoppe (2003) also show that these models are equivalent to the basic model of rent seeking. 
it is not possible to evaluate the software invention. Such complementarity effects are not confined to inventions but often involve other resources. For example, a decrease in the price of natural gas may increase the demand for production technologies that affect the costs of using natural gas. Without knowing the effects of changes in the price of natural gas, it is not possible to evaluate competing production technologies.

Fifth, in contrast to prizes in tournaments, the price of inventions is not an end in itself. The contest ends when the prize is awarded. However, as Kitch (1977) points out, the "rewards" view of patents is inaccurate because patents provide IP protections for investments in development and commercialization that occur after the patent is granted. The market for inventions provides rewards based on the additional efforts of inventors and adopters of inventions. This includes investments in developing complementary technologies and investments in assets that will be used to apply the invention. In addition, the market for inventions includes the entire process of licensing or transferring the invention, improving the invention, and applying the invention.

Sixth, in contrast to government contests, competition in the market for inventions is a learning process. In designing a contest, government agencies must specify what are the rules and objectives of the contest before knowing the technologies that will be discovered. Then, government agencies must determine criteria for choosing the best invention before knowing how the technologies will be applied by producers. Government agencies also must determine the best invention before knowing how consumers will evaluate new products or transaction methods. Government agencies must determine prizes before knowing the value of inventions.

In contrast, market competition takes place after inventions are made and decision makers can respond to the characteristics of discoveries. Market competition benefits from extensive information revealed by $R \& D$ and additional information revealed by the application of inventions. Also, market competition responds to the choices of adopters as they experiment with the application of different technologies. Market competition benefits from learning about consumer reactions to new products and transaction methods. Most goods and services need market testing; who knows in advance what is the best car, the best software, or the best ice-cream? Market competition involves the determination of prices of inventions which provides information about the value of those inventions. As Hayek (2002, p. 9) points out, competition is a discovery procedure: "it is useful to recall that wherever we make use of competition, this can only be justified by our not knowing the essential circumstances that determine the behavior of the competitors" (emphasis in original).

\section{B. Prices and Gains from Trade}

The pro-prize argument maintains that a prize will perform the same functions as a market price because it will provide incentives for invention. This argument is flawed because it views market prices as rewards for inventors. This is a fundamental 
misunderstanding of market prices. Both parties benefit from economic transactions both parties receive gains from trade - because transactions are voluntary.

Market prices provide rewards to both buyers and sellers because they are the terms of exchange. In markets for consumer goods, buyers receive surplus from transactions equal to the benefits of consuming goods and services net of payments to sellers. Sellers receive benefits from transactions equal to payments from buyers net of the sellers' costs of providing goods and services.

Market prices of inventions provide rewards to both IP owners and IP users. In the market for inventions, exchange of IP through licensing, cross-licensing, transfers, and contracts benefit both IP owners and IP users. Replacing the price system harms both buyers and sellers of IP by removing the transactions that generate gains from trade.

Another problem with the view that prices are rewards for sellers is that prices are mechanisms of competition. Eliminating the price mechanism for IP would harm buyers and sellers by reducing price competition: buyers bid competitively to attract sellers and sellers bid competitively to attract buyers. This applies generally and also to markets for inventions and to innovative competition in markets for goods and services. Prices for inventions and innovations are essential to competition throughout the economy. Prices of inventions can be explicit, as is the case with patent licensing and patent transfers. Prices of inventions can be implicit, as is the case with cross-licensing, contract $R \& D$, inventions embodied in goods and services, and securities of corporations that own inventions. Replacing market prices for inventions with government prizes would eliminate the benefits of market competition.

Competition stimulates invention and innovation when there is a market for inventions (Spulber, 2013 a,b). Entry of competing inventors improves the expected quality of inventions and also increases competition in royalties and the prices of patent transfers. Better inventions and lower royalties increase the returns to entry of producers in product markets, leading to increased competition downstream and more innovation. Conversely, competition in product markets by producers that obtain technology in the market for inventions increases industry output in the product market, which in turn stimulates demand for technological inventions. This increases economic rents for inventors, which encourages entry of inventors and investment in $\mathrm{R} \& \mathrm{D}$, thus increasing inventive effort and improving the expected quality of inventions.

Prices in the market for inventions also are instruments of cooperation. Prices reflect the terms of trade between buyers and sellers. Negotiation of royalties depends not only on the features of the invention but also on the application of the invention. Patented inventions are a form of technology capital that can be used by multiple firms, in multiple locations, and in multiple productive activities. ${ }^{45}$ Patented inventions can be applied to

${ }^{45}$ For a discussion of technology capital, see McGrattan and Prescott (2009). I employ the term technology capital because it suggests that it can be applied productively by firms. The term "knowledge capital" seems too broad for the purposes of the present 
generate returns through licensing, cross licensing, and sales. Patented inventions also can be applied by firms to develop innovations, including new products, production processes, and transaction methods. Patented inventions also can be applied to create new inventions. Economic efficiency suggests that the price of an invention can vary depending on applications of the invention.

Prices in the market for inventions depend on many critical factors. Epstein and Malherbe (2011) find that a careful economic analysis is required in calculating damages from infringement and urge caution in considering comparable royalties from other patents. Epstein and Malherbe (2011, p. 8) point out that "For example, one patent may be economically 'strong' (in the sense that the specific technology has no close and inexpensive substitute) while another may be economically 'weak' because commercially acceptable alternatives or design-arounds are readily available." Negotiated royalties depend on features of the transaction: "When a patent's value is derived from reducing manufacturing costs, the cost savings for different patents or even different applications of the same patent may not be the same. Differing degrees of licensing exclusivity, duration, field of use, and potential overlap and competition with the patent holder's own sales could influence the royalty." ${ }^{, 46}$ Epstein and Malherbe $(2011$, p. 8) also find that negotiated royalties depend on commercialization and innovation: "Patents may also differ in the amount of additional investment required to achieve commercialization, including research and development, production facilities, product testing and regulatory approvals, marketing, and acquisition of additional intellectual property rights." Finally, they observe "royalties in other licenses may be part of a complex transaction that includes joint licensing of other patents (i.e., patent pooling), cross-licenses, know-how, and/or product support, as noncash features of the deal." ${ }^{47}$

\section{Public Goods and Natural Monopoly}

The theory of public goods suggests that there are cost advantages to providing the same public good to all consumers. Usage of public goods is non-rivalrous and distribution costs are equal to zero. Providing the same public good to all consumers is efficient because production costs are not duplicated by multiple providers.

If inventions are pure public goods, prize advocates suggest that it would be efficient for the market to be served by a single invention. Based on this argument, prize advocates recommend that the government should identify a "best invention" through prize contests and make this invention available to all producers at a zero price.

discussion. On the production and distribution of knowledge, see Machlup (1962) and Griliches (1979). Technology capital also is distinct from human capital. Becker (1962, p. 9) defines investment in human capital as those "activities that influence future real income through the imbedding of resources in people."

${ }^{46}$ Epstein and Malherbe $(2011$, p. 8).

${ }^{47}$ Epstein and Malherbe (2011, p. 8). 
The economic theory of public goods is very similar to the theory of natural monopoly. As Baumol and Willig (1981, p. 405) observe "the resource allocation problems that stem from fixed costs are formally identical with those that accompany public goods - both their sources and their character are the same. Thus, the rationale for public supply of public goods may be no different from that pertaining to nationalization of natural monopolies." If inventions are public goods, this argument would suggest that there is an economic rationale for either public supply of inventions or government taking of inventions through nationalization.

The natural monopoly argument for public utility regulation or nationalization is that it is more efficient for the market to be served by a single firm rather than two or more firms. The formal definition of natural monopoly refers to a static cost function. ${ }^{48}$ The cost function exhibits the natural monopoly property if the costs of producing a particular output level by a single firm are less than the costs of producing that output by two separate firms. This definition extends readily to the costs of producing multiple products. The cost function exhibits the natural monopoly property if the costs to a single firm of producing multiple products are less than the costs of producing those products by two separate firms.

The public good or natural monopoly framework does not transfer to invention. The standard public good or natural monopoly arguments apply to production of a homogeneous good. Suppose that the cost of producing street lighting involves a fixed cost of $\$ 100$. Many consumers benefit from the same street lighting, so that it is not necessary to incur the fixed cost more than once. Such an argument would not apply to the production of inventions. Suppose that the cost of producing an invention involves a fixed cost of $\$ 100$. Unlike the production of street lighting, invention is not a deterministic activity and the outcome of invention is not a homogeneous good.

Invention is not a natural monopoly. The outcome of invention is subject to considerable uncertainty that generally requires multiple inventive efforts. Far from being a generic activity, R\&D involves creative effort. Invention requires not only inspiration but also many different approaches. There are many different types of R\&D in technology, science, the social sciences, and other areas. Even within narrow areas of inquiry, there is significant trial and error and disagreements about how to address various research problems and what are the problem being addressed. There is considerable specialization and division of labor in R\&D.

These diverse activities cannot be readily agglomerated into a single enterprise for the economy as whole. There may well be fixed costs and other sources of economies of scale in R\&D. However, a central government laboratory would not be sufficient to produce all inventions for an economy. There would still be a need for many research

${ }^{48}$ See Baumol et al. (1988) and Spulber (1989). 
facilities in the economy. Thus, invention should not be viewed as a natural monopoly that should be regulated or nationalized to attain zero marginal cost prices.

What about the usage of inventions after they are produced by R\&D? Nonrivalrous consumption implies that the same invention can be used by multiple producers. The fixed costs of invention have already been incurred and are sunk, so that these costs need not be considered in the allocation of inventions. If there are fixed costs in the procurement of inventions from inventors or in the distribution of inventions, economic efficiency would suggest that only one invention should be used by all. That is, public good or natural monopoly arguments would suggest that only one invention should be used.

However, inventions are not homogeneous goods. The features of inventions can differ in complicated ways so that there need not be a "best" invention in a set of substitute inventions. There is often a need for multiple inventions that address the same problem, just as there is a need for multiple novels, movies, songs, or other creative works. An individual consumer derives benefits from product variety so that a consumer may prefer to use multiple inventions that are substitutes in demand. Also, consumers may have different needs so that there cannot be just one headache remedy or just one medicine for high blood pressure. Producers differ as well so that different producers may prefer to apply different inventions in product designs, production processes, and transaction methods.

The notion that there is a best invention that should serve the entire market is a static efficiency concept. The public good and natural monopoly concepts provide static views of economic efficiency (Spulber, 1995). However, technological change is an inherently dynamic process. Different efficiency concepts apply because of technological change. It may no longer be efficient for a particular invention to serve the entire market.

To illustrate the problems that can arise from applying static efficiency concepts to invention and innovation, consider how dynamic consideration affect the efficient outcome. Consider first a static setting without technological change. Suppose that there is a set of inventions that have the same features and suppose that producers make technology decisions at the same time. Suppose also that there are fixed costs associated with distributing those inventions. It may then be efficient by standard public good or natural monopoly arguments for all producers to adopt one invention. The notion that inventions are public goods or natural monopolies suggests that only one technology should be in use.

Now consider a two-period setting with technological change such that better inventions appear in the second period. It may be efficient for some producers to adopt an invention in the first period and to continue using that invention in the second period. It may be efficient for other producers to wait until the second period to adopt the better technology. This implies that even though there are fixed costs of distributing inventions, it may be more efficient for there to be two inventions in use in the second period. This 
implies that an invention need not be a natural monopoly. Even if inventions have public good properties, it may be more efficient for multiple inventions to be in use at the same time.

In addition to technology change, consumer preferences and needs change over time. In addition, changes in market demand and other market conditions will change the needs of producers. Different inventions will be required over time to produce new products, production processes and transaction methods. Again, it may be more efficient for multiple inventions to be in use at the same time as adoption decisions may occur in different periods.

\section{Market Prices and Guidance for Technological Decisions}

Prices in the market for inventions provide important economic signals that guide the decisions of inventors, producers, and investors. An important feature of prices in the market for inventions is that they are state-contingent. Market prices for inventions are contingent on the features of inventions and the features of substitute and complementary inventions. Because prices for inventions adjust to technological changes, which are necessarily unexpected, they provide valuable guidance for decision making under uncertainty. This is particularly important because prices in the market for inventions are likely to change continually over the twenty year life of a patent.

\section{A. Information: Prices versus Prizes}

Eliminating the price mechanism for IP would harm both buyers and sellers who benefit from the information content of prices. Prices of inventions are particularly significant because they provide convenient indicators of technological change. Prices for inventions and innovations provide extensive information to buyers and sellers. Because technology is an input to production, producers' demand for the technology is a derived demand - it depends on the demand for the producers' final products. Increases in the prices of inventions can reflect increases in consumer demand for products that are produced using the inventions or whose design is based on the inventions.

A price offers highly condensed information because just one number summarizes an enormous amount of information in a way that everyone can understand. A price describes the terms of a transaction by specifying the amount of a given currency that can be exchanged for the provision of a particular good or service. Market actors can observe the information contained in prices without having to know all the details of supply and demand. The information contained in prices is highly useful because decision makers can compare prices of very different goods and services. Decisions makers can compare prices across periods of time, in different locations and in different currencies. Decision makers can use prices to aggregate of disaggregate total expenditures or total revenues corresponding to bundles of goods and services. 
A key aspect of the patent system is that the market prices of inventions generally are determined after discoveries take place. This contrasts with the fixed nature of government prizes, which are determined by policy makers before discoveries take place. Market prices adjust to information about scientific and technological discoveries and convey information about those discoveries. Prizes are awards that are arbitrarily established by government agencies and do not depend on scientific and technological discoveries nor do they convey information about these discoveries. Roin (2014) points out that patents allow the rewards to owners to vary over time reflecting changes in the value of inventions, giving patents an important advantage over static "prizes" with common ownership.

After receiving a patent grant, an inventor licenses the invention or transfers the invention to others. Licensing royalties and transfer prices result from transactions among market participants and reflect information about the features of inventions. Because patents cover development of inventions, market prices change continually as additional features of the patented invention emerge. Market prices of patented inventions also change continually as a result of commercialization efforts of patent owners and the emergence of new applications of the patented inventions. In addition, market prices of patented inventions change continually to reflect the development of substitute and complementary technologies.

Prices summarize market conditions and change in response to market transactions. Whether for goods and services or inventions, market equilibrium prices result from competition among buyers for scarce products and competition among sellers to provide products. Market prices can be posted by buyers or sellers, they can result from negotiation, they can be chosen by intermediaries, or they can be established though organized auctions and other bidding mechanisms. Market prices are affected by the willingness to pay of the buyers in the market place and the costs of sellers in the market place. Buyers' willingness to pay depends on their preferences, incomes, and availability of substitutes and complements. Sellers' costs depend on their technologies, costs of capital, labor, resources, and IP. The resulting market prices summarize this vast amount of information in a way that provides useful information to buyers, sellers, and other market participants.

Prices in the market for inventions reflect transactions between many types of market participants, including inventors, innovators, producers, investors, and consumers. These prices are the result of many millions of individuals engaging in search, marketing, negotiation, buying, selling, and contracting. The prices also are affected by underlying efforts in R\&D, commercialization of inventions, and innovation in products, production processes, and transaction methods. Market prices also reflect the costs of complementary investments in product design, manufacturing equipment, and wholesale and retail distribution. 


\section{B. Inventors}

Prices in the market for inventions provide guidance because they depend on information about scientific and technological discoveries and economic innovations. Anticipation of these state-contingent incentives helps inventors choose R\&D projects and determine the extent of effort to devote to particular R\&D projects. State-contingent prices also guide inventors in developing and commercializing patented inventions.

Inventors benefit from state-contingent prices for inventions without the need to specify those contingencies in advance, as would be the case with a state-contingent contract. The state-contingent nature of market prices also implies that prices will continually change in response to inventions and innovations. Prices of patented inventions continue to vary based on discoveries and market forces. The highly complex system of state-contingent prices contrasts with a government prize system that sets a one-time fixed prize for a single winner.

Inventors are necessarily engaged in planning under uncertainty. R\&D projects are subject to various forms of risk and uncertainty. The researcher is engaged in developing knowledge and so may not be able to formulate even the basic questions. When designing and conducting experiments, the inventor does not know what will be the outcome of basic research and generally does not know the likelihood of alternative outcomes. Although R\&D involves extensive study, preparation, and effort, unexpected outcomes may occur that appear serendipitous and even "easy" to outside observers. In the process of conducting $\mathrm{R} \& \mathrm{D}$, the inventor often acquires tacit knowledge that is difficult to codify and communicate to others; see Spulber (2012) for further discussion and an economic model of tacit knowledge.

Inventors engage in multiple research tasks that are needed to formulate the problem, conduct experiments, and develop inventions based on discoveries. There can be multiple outcomes for any particular R\&D project. Researches often choose among multiple R\&D projects each of which has different sets of outcomes. Researchers make multiple decisions over time, adding and removing activities from their R\&D projects. The R\&D process often cannot be described in advance by a single outcome with a specific economic value.

The state-contingent nature of market prices provides important guidance for decision making under uncertainty. To illustrate how decision making can be guided by state-contingent prices, let $s=1,2, \ldots, S$ denote possible states of the world corresponding to different outcomes of a particular R\&D project. Let $a_{s}$ represent the

probability that the outcome of R\&D will be state $s$, where $\sum_{s=1}^{S} a_{s}=1$. Because R\&D is inherently uncertain, the probabilities can represent the inventor's Bayesian subjective beliefs about the likelihood of outcomes of R\&D. For purposes of discussion, suppose that the inventor has expectations about the market price of the invention that corresponds to each outcome of R\&D. The market price $r$ can be viewed as a random variable, where $r_{s}$ represent the market price that is observed when state $s$ is the outcome 
of the R\&D project. The inventor's R\&D project can be viewed as a security with payoffs $r_{s}$ in state $s$. The inventor can determine the expected price $E r=\sum_{s=1}^{S} a_{s} r_{s}$, which is the expected value of the R\&D project. ${ }^{49}$

The inventor's price expectations provide guidance for various types of decisions generally associated with investment projects. The inventor can choose to undertake an $\mathrm{R} \& \mathrm{D}$ project if the project has a positive net present value (NPV), that is, if the expected value of the project exceeds its costs. ${ }^{50}$ The inventor can choose among a set of projects by comparing their NPVs and the inventor can choose to allocate resources across a portfolio consisting of multiple R\&D projects. If the inventor is risk averse, then the inventor can consider the expected utility of the project given the variation in prices across outcomes of $R \& D$ and the likelihood of the various states of the world. These standard aspects of financial decision-making carry over to decisions about invention and innovation.

The state-contingent nature of prices also is useful in deciding whether to invest in further development and commercialization of a patented invention. Suppose that after an invention has been granted a patent, an inventor must incur an additional cost of development and commercialization. Let $K$ denote the additional development and commercialization costs. The inventor often will benefit from gathering additional information about the market value of the invention before choosing whether or not to develop the patented invention. The patented invention then is a "real option" for the patent owner because the owner invests only if the market value of the invention exceeds investment costs. The economic value of the patented invention takes the form of an option because the patent owner invests only if the price exceeds the cost of investment, $v_{s}=\min \left\{r_{s}-K, 0\right\}$. The expected value of the project is the expected value given that the patent owner only invests in those states in which the price exceeds the cost of investment, $E v=\sum_{s=1}^{S} a_{s} v_{s}$. The project has a greater expected value than it would if the patent owner had to make an investment decision before observing the market price.

The inventor's R\&D decision-making anticipates the combination of patent protections for prospective claims and state-contingent market prices. The inventor's incentives to invent are increased by patent protections for investments that occur after the patent is granted. This is because exercising an option after gathering additional information increases the expected value of the invention in comparison with the

49 There also can be market uncertainty, in which case we can consider $p_{s}$ as the expected market price in state $s$.

${ }^{50}$ For example, suppose that $k$ represents the costs of the R\&D project and $i$ is the appropriate discount rate given the risks associated with the R\&D project. The net present value of the R\&D project is of $N P V=\frac{E r}{1+i}-k$. 
expected present value of the project when investment decisions are made before gathering information.

Patents protect the inventor's IP after the patent is granted, including development of the invention and investment in commercialization and innovation. In this way, the inventor's IP is a state-contingent claim that includes both residual returns and residual control. In this way, patents as prospective claims increase incentives to invent and to innovate. This supports Kitch's (1977) observation that patents serve a valuable function by protecting the investment-backed expectations of their owners after the patent is granted. A number of studies have considered the role of patents as real options. Innovation is a real option when the returns to developing an invention are greater than the costs of investment (Erkal and Scotchmer, 2009). Pakes (1986) and Schankerman and Pakes (1986) study patent renewals as options that are exercised when the value of the patent exceeds the costs of renewal. Ziedonis (2007) studies corporate sponsorship contracts for university research that include an option to purchase.

The state-contingent nature of market prices also serves to guide investors that provide financing for invention and innovation. Patented inventions are intangible real assets that are created through investment in research and development (R\&D). Market transactions determine prices for patented inventions in a similar manner to other types of assets. Patents owned by corporations are intangible real assets that affect the market value of the firm. Patents are an important form of collateral for secured debt and companies using patents as collateral perform a significant share of R\&D (Mann, 2014). Graham et al. (2009) find that startups that patent benefit in terms of greater venture capital financing and that startups funded by venture capital tend to hold more patents than startups with other types of funding.

\section{Producers}

Licensing rates often are determined through complex contractual negotiations that reflect not only the particular characteristics of the technology but also how the patented invention will be applied by a potential adopter. Thus, prices are not only statecontingent, but depend on the characteristics of particular buyer-seller transactions.

To consider the effects of changes in the per-unit royalty rate on producers, let $r$ be the royalty rate per unit of output $q$. Suppose that the firm's operating profit using the new technology is $\Pi(q)$, so that the firm's net profit equals $V=\Pi(q)-r q$. Given the royalty rate $r$, the firm chooses the profit-maximizing output $q^{*}$ by equating the marginal profit from using the new technology to the per-unit royalty rate, $\frac{d \Pi\left(q^{*}\right)}{d q}=r$.

The producer's profit-maximizing output can be expressed as a function of the per-unit royalty $q^{*}(r)$. The firm's net profit then can be expressed as a function of the royalty rate $V(r)$. The effect of a change in the royalty on the firm's net profit equals the 
firm's profit-maximizing output, ${ }^{51} \frac{d V(r)}{d r}=q^{*}$. The producer will pass through to consumers some of the royalty costs, see Weyl and Fabinger (2013) on the general theory of cost pass through with imperfect competition.

Royalties and the characteristics of the technology influence firms' technology adoption decisions. The per-unit royalty $r$ and the up-front lump-sum royalty $R$ are critical determinants of producers' technology adoption decisions. A producer faced with only one technological possibility will adopt the technology only if it generates returns, $V(r) \geq R$. Royalties also can affect producers' market entry decisions.

Competing technologies will yield different operating profits. Consider the returns from two competing technologies, $V^{1}(r)$ and $V^{2}(r)$. A producer will choose the technology that generates the greatest returns net of royalties. ${ }^{52}$ The producer will compare a new technology with existing technologies and also will consider the possibility that better technologies may become available in the future.

\section{Market Prices and Technological Change}

Prices in the market for inventions serve an exceptionally important function by providing highly condensed information about technological change. By comparing prices of inventions over time and across inventions, it is possible to make inferences about the effects of technological change. Some improvements in technology can be expected to reduce the quality-adjusted prices of products that embody inventions. These important properties of market prices contrast with once-and-for-all government prizes.

\section{A. Prices and Process Innovation}

To illustrate the effects of technological change on prices, consider a basic description of the market for inventions. Inventors invest resources in R\&D and generate a series of inventions. Although technological change is subject to considerable uncertainty and randomness, assume for simplicity that inventors create a new generation of technology that arrives regularly at each date $t$, which can represent periods denominated in months. Although there are competing inventions at each date, a bundle of the best inventions at each date constitutes that generation of technology.

The generation of inventions that arrives at each date results in improvements in production technology, known as process innovation. To represent process innovation, let $c_{t}$ denote the unit costs of production when using the generation of inventions that becomes available at date $t$. Let $c_{0}$ be the unit cost given the initial technology. Suppose

\footnotetext{
${ }^{51}$ By standard arguments, this result it follows from taking into account the producer's optimization and applying the envelope theorem.

${ }^{52}$ The producer will compare $V^{1}\left(r^{1}\right)-R^{1}$ with $V^{2}\left(r^{2}\right)-R^{2}$.
} 
that each new generation of technology improves on the previous generation so that applying the technology causes unit costs of production to decline, $c_{t}>c_{t}+1$. This represents the manner in which technology changes with each generation. Process innovations can include assembly lines, use of new materials, robotics, computer-aided design and manufacturing $(\mathrm{CAD} / \mathrm{CAM})$, and other improvements in manufacturing techniques.

Inventors compete to sell their inventions to producers in the market for inventions. Inventions not only compete within each generation but also compete with inventions in previous generations and future generations. Because better technology appears at each date, suppose for purposes of illustration that competition from the new generation of technology causes royalties for each generation of inventions to fall to zero the next date after they are introduced. The new generation of technology replaces the previous generation of technology.

Consider now royalties for inventions in the period that they are introduced. Let $r_{t}$ represent the initial total royalties per unit of output for the bundle of the best inventions that becomes available at date $t$. For ease of discussion, suppose that each producer produces one unit of output, so it is not necessary to distinguish between per-unit royalties and up-front lump-sum royalties. Technology introduced at date $t$ competes with the previous generation which then has a zero royalty. Producers will only adopt the new generation of technology if doing so lowers their unit production costs plus per-unit royalties. Recall that competition from the current generation of technology lowers the royalties of previous generations of technologies to zero. This implies that the sum of the current period royalties and unit costs cannot exceed unit costs under the previous generation of technology, $r_{t}+c_{t} \leq c_{t-1}$.

Royalties in each period are thus subject to a competition constraint based on the previous generation of technology. Arrow (1962) points out that such a competition constraint on royalties may or may not be binding for a new technology. If inventors with the best inventions have market power and inventions are incremental relative to the earlier technology, the competition constraint may be binding. Then, the total of royalties and unit costs will be unchanged after the new generation of technology is adopted. However, if inventors with the best inventions have market power and improvements in technology are sufficiently "drastic, inventors may choose royalties that are low enough such that the competition constraint will be non-binding. Then, the total of royalties and unit costs will be strictly lower than that of the previous generation after the new technology is adopted. Competition among inventors within each generation of technology can also strictly reduce the total of royalties and unit costs.

The unconstrained royalty in the period that the new technology is introduced depends on the characteristics of the new technology. Let $r^{*}\left(c_{t}\right)$ denote the unconstrained royalty that reflects competition among inventors providing the new technology at date $t$. This equals the monopoly royalty if suppliers of the best inventions have monopoly 
power or it is less than the monopoly royalty with competition among inventors. Because each new generation of technology also competes with the previous technology, which has a zero royalty starting the next date after it is introduced, it follows that the royalty at each date is given by the minimum of the incremental contribution of the new technology and the unconstrained royalty, $r_{t}=\min \left\{c_{t-1}-c_{t}, r^{*}\left(c_{t}\right)\right\}$.

If the set of inventions is drastic, a monopoly inventor will choose royalties strictly below the incremental contribution of the new technology. Also, with sufficient competition among inventors within each generation of technology, royalties will be strictly below the incremental contribution of the new technology. Otherwise, royalties will be equal to the incremental contribution of the new technology.

Finally, consider the final product market for goods and services. ${ }^{53}$ Suppose that this market is perfectly competitive so that final product prices equal unit costs of production plus the royalty per unit of output, $p_{t}=r_{t}+c_{t}$. The market price is greater than or equal to current unit cost because current royalties are greater than or equal to zero, $p_{t} \geq c_{t}$. The competition constraint guaranties that royalties plus unit costs in the next period will be lower than current unit costs, so that prices in the next period will be lower than current unit costs, $c_{t} \geq r_{t+1}+c_{t+1}=p_{t+1}$.

So, combining technological change and the competition constraints in the market for inventions implies that product prices decrease with each generation of technology, that is, $p_{t} \geq p_{t+1}$. Depending on the extent of the process innovation and the degree of competition within each generation of inventions, product prices may decline slowly or rapidly. In this way, product prices can provide a condensed indicator of technological change with process innovations.

\section{B. Prices and Product Innovation}

A similar analysis can be applied to product innovation. To represent product innovation, denote the quality of final output when using the current generation of technology by $q_{t}$. Suppose that this measure of product quality is comparable across technology generations. For example, this can be a quality measure such as durability, energy efficiency, battery life, screen resolution, microprocessor speed, or digital memory storage capacity. Suppose that each new generation of technology improves on the previous generation so that applying the technology causes product quality to increase, $q_{t}<q_{t+1}$.

As before, let $r_{t}$ represent the total royalties per unit of output for the bundle of the best inventions during the period that they become available. Let $c_{t}$ represent unit production costs of manufacturing the new generation of products. Unit production costs may increase or decrease with each new generation because it may be more or less costly

${ }^{53}$ The price is given by the sum royalties and unit costs, $p_{t}=r_{t}+c_{t}=\min \left\{c_{t-1}, r^{*}\left(c_{t}\right)+\right.$ $\left.c_{t}\right\}$. 
to produce the higher-quality product. New generations of technology can involve combinations of product and process innovations.

Because of competition in the market for inventions, suppose again for purposes of illustration that price competition with the next generation of technology causes royalties for each generation of technology fall to zero in the period after it is introduced. Then, producers will not adopt the new generation of technology unless quality-adjusted royalties plus unit production costs are lower than quality-adjusted costs under the previous generation, $c_{t} / q_{t} \geq\left(r_{t+1}+c_{t+1}\right) / q_{t+1}$. Production costs for producers using the new generation cannot be too high so that there is room to allow positive royalties for the new generation of technology. ${ }^{54}$

As with process innovation, suppose that the product market is perfectly competitive so that final product prices equal unit costs of production plus the royalty per unit of output, $p_{t}=r_{t}+c_{t}$. As before, the market price is greater than or equal to current unit cost because current royalties are greater than or equal to zero, $p_{t} \geq c_{t}$. This also holds if we adjust both prices and costs for quality, $p_{t} / q_{t} \geq c_{t} / q_{t}$. Competition in the market for inventions implies that quality-adjusted unit costs are greater than quality-adjusted prices in the next period, $c_{t} / q_{t} \geq\left(r_{t+1}+c_{t+1}\right) / q_{t+1}=p_{t+1} / q_{t+1}$.

So, the combination of technological change and product market competition has the important implication that quality-adjusted product prices decrease with each

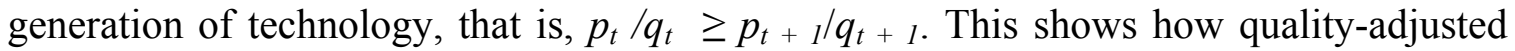
product prices can provide a condensed indicator of technological change with product innovations.

\section{An Illustration of Price Changes with Product Innovation}

To illustrate how prices provide condensed indicators of technological change consider changes in the quality-adjusted prices of microprocessors. For ease of discussion, let Moore's Law summarize the complex technological changes in microprocessors. Moore's Law predicts exponential technological change: the number of electronic components that can be put on a chip doubles every 24 months (Moore, 1965, Moore, 1995). Electronic components include transistors, resistors, diodes, and capacitors (Moore, 1995).

Moore's Law has accurately described this aspect of technological change in microprocessors for a period of about fifty years. Moore's Law is a very basic description of some effects of highly complex changes in technology, many of which were discovered long after the prediction. Two significant production processes for microprocessors motivate Moore's Law. First, the diffusion and oxide-masking process

${ }^{54}$ This requires that $\left(r_{t}+c_{t}\right) / q_{t} \geq c_{t+1} / q_{t+1}$. 
allowed the use of photographic techniques in producing semiconductors. ${ }^{55}$ Second, the planar process allowed the use of lithography to make electronic connections on a flat wafer of silicon. ${ }^{56}$

The patenting process played a role in these critical developments according to Moore (1998, p. 59),

"When the patent application for the planar transistor and the process for making it was being prepared for filing, having been made aware of our view of the importance of this invention, the patent attorney asked if we had thought through the implications of the invention to be sure that we were covering it sufficiently." This question led to consideration of further developments of the invention,

"To consider this question, Noyce assembled a meeting of the key technical people in the Research and Development Department at Fairchild to discuss how [Jean A.] Hoerni's invention might be extended. ... During this session, Noyce described how the planar idea could be extended to make complete circuits rather [than] just individual components."

The result was a fundamental invention in microprocessor technology,

"At this meeting, Noyce described all the additional features necessary to extend the planar transistor technology to make a practical structure for an integrated circuit. He was eventually awarded a patent on the key idea of interconnection [R. N. Noyce, U.S. Patent 2981 877, Apr. 25, 1961], although his insight was much broader." 58

Noyce's patent illustrates the forward-looking nature of patented inventions.

The diffusion and planar processes not only increased the density of devices on a chip but also lowered production costs. This motivated the original prediction; Gordon Moore recalled "from where I was in the laboratory, you could see the changes that were coming, make the yields go up, and get the cost per transistors down dramatically."59 However, Moore (1995, p. 14) became concerned that the production costs of microprocessors also were growing at an exponential rate.

The question to be addressed is whether quality-adjusted prices of computer chips changed systematically. As a rough illustration, I compiled a list of Intel microprocessors using the number of transistors as a measure of quality. I tried to obtain the price for the most basic version of each microprocessor in terms of processing speed. See Aizcorbe and Kortum (2005) for a more detailed empirical analysis that tests a capital vintage

${ }^{55}$ Schaller (1997, p. 54).

${ }^{56}$ Schaller (1997, p. 54).

${ }^{57}$ Moore (1998, p. 59) ("I was not at that meeting, since my responsibility at the time was to oversee the engineering effort to get our transistors into production.").

${ }^{58}$ Moore (1998, p. 59).

${ }^{59}$ Intel Corporation (2005). 
model by considering average prices within each generation and examining how prices of each generation decline over time.

To adjust for inflation, I list the price of the microprocessor in the year that it was introduced and convert to 2013 dollars. ${ }^{60}$ Then, I divide the inflation-adjusted price by the number of microprocessors. This gives only a snapshot of technological change. The quality-adjusted price indicates the effects of improvements in Intel's fabrication processes $\left(45 \mathrm{~nm}\right.$ in $2008,32 \mathrm{~nm}$ in $2010,22 \mathrm{~nm}$ in 2012). ${ }^{61}$ However, there were also other major technical achievements such as the three-dimensional Tri-Gate transistor introduced by Intel in its Ivy Bridge microprocessors. ${ }^{62}$ Intel's microprocessors offered many other improvements in quality that are not reflected in my very basic method of calculating quality-adjusted prices. There is also a slight departure from the trend due to the Pentium III, which appears to be a bargain. With these caveats in mind, the rapidly decreasing quality-adjusted prices shown in Table 1 give a clear indication of the many technological changes that occurred in microprocessors over the period of four decades. This illustrates how prices serve as a condensed indicator of technological change.

\footnotetext{
${ }^{60}$ I used the bureau of labor statistics calculator, http://data.bls.gov/cgi-bin/cpicalc.pl?cost1=5.25\&year1=1980\&year2=2013.

${ }^{61} \mathrm{http}: / /$ hexus.net/tech/reviews/cpu/37989-intel-core-i7-3770k-22nm-ivy-bridge/

${ }^{62}$ http://hexus.net/tech/reviews/cpu/37989-intel-core-i7-3770k-22nm-ivy-bridge/
} 


\begin{tabular}{|l|l|l|l|l|}
\hline Microprocessor & $\begin{array}{l}\text { Year of } \\
\text { introduction }\end{array}$ & $\begin{array}{l}\text { Number of } \\
\text { transistors }\end{array}$ & $\begin{array}{l}\text { Price in 2013 } \\
\text { dollars } \\
\text { (Nominal } \\
\text { price) }\end{array}$ & $\begin{array}{l}\text { Quality- } \\
\text { adjusted price } \\
\text { in Dollars per } \\
\text { transistor }\end{array}$ \\
\hline 4004 & 1971 & 2300 & $172.56(30)$ & 0.0750 \\
\hline 8080 & 1974 & 4500 & $\begin{array}{l}1,701.11 \\
(360)\end{array}$ & 0.3780 \\
\hline 8086 & 1978 & 29,000 & $\begin{array}{l}1,286.27 \\
(360)\end{array}$ & 0.0443 \\
\hline Intel286 & 1982 & 134,000 & $869.06(360)$ & 0.0065 \\
\hline Intel386 & 1985 & 275,000 & $647.34(299)$ & 0.0024 \\
\hline Intel486 & 1989 & $1,200,000$ & $\begin{array}{l}1,690.82 \\
(900)\end{array}$ & $1409 \cdot 10^{-6}$ \\
\hline Intel Pentium & 1993 & $3,100,000$ & $\begin{array}{l}1,415.48 \\
(878)\end{array}$ & $456.6 \cdot 10^{-6}$ \\
\hline Intel Pentium II & 1997 & & $724.27(499)$ & $96.57 \cdot 10^{-6}$ \\
\hline Intel Pentium III & 1999 & $7,500,000$ & $334.19(239)$ & $11.94 \cdot 10^{-6}$ \\
\hline Intel Pentium 4 & 2000 & $28,000,000$ & $871.22(644)$ & $20.74 \cdot 10^{-6}$ \\
\hline Intel Itanium 2 & 2004 & $42,000,000$ & $\begin{array}{l}1,445.34 \\
(1172)\end{array}$ & $6.570 \cdot 10^{-6}$ \\
\hline Intel Core 2 Duo & 2006 & $220,000,000$ & $612.44(530)$ & $2.105 \cdot 10^{-6}$ \\
\hline $\begin{array}{l}\text { Intel Core } 2 \\
\text { Quad }\end{array}$ & 2007 & $291,000,000$ & $269.65(240)$ & $0.4633 \cdot 10^{-6}$ \\
\hline Intel Core i3-530 & 2010 & $582,000,000$ & $120.72(113)$ & $0.3160 \cdot 10^{-6}$ \\
\hline Intel Core i7-377 & 2012 & $382,000,000$ & $309.47(305)$ & $0.2210 \cdot 10^{-6}$ \\
\hline
\end{tabular}

Table 1 Quality-adjusted prices of selected Intel microprocessors 1971-2012.

\section{Conclusion}

The America COMPETES Reauthorization Act opens the door to replacing market prices with government prizes. The Act gives prize authority to the heads of every government agency. Although transferring patented technology to the government is "voluntary," such transfers can be a condition for participating in prize contests. Additionally, the government has an array of powerful instruments for inducing participation in prize contests, including research grants, subsidies for research by universities, labs and corporations, tax credits and penalties for individuals and corporations, government procurement rules, and economic regulation of industry. 
Although seemingly benign, contests combined with transfers of IP to the government would harm invention and innovation. In contrast to market prices for inventions, a system of government prizes with either public or common ownership, would apply command-and-control to innovation. The government would determine the "shadow prices" of inventions, select the winning inventions, pay rewards to inventors, and allocate technologies to potential users. If only central planners could find the right "shadow prices", they could replace market prices with government prizes, thus avoiding the need to solve "millions of equations". But the premise is inconsistent with experience in centrally planned economies.

Central planners necessarily lack the detailed private information of inventors, innovators, producers, and consumers that generate prices in the market for inventions. Government prizes would fail to reflect the extensive private information contained in market prices and would fail to adjust continually to changes in economic conditions, including technological change. Central planners cannot match the knowledge of Hayek's "man on the spot" for goods and services. Central planners are even less equipped to match the knowledge of scientists, engineers, entrepreneurs, and managers engaged in invention and innovation. Market systems perform much better than governments in diffusing inventions and innovations.

Market prices are instruments of cooperation between inventors and producers. Market prices are also mechanisms of competition among inventors and among producers. Market prices for inventions help coordination the diffusion of technology and the application of technology to innovation. Antitrust and regulations that weaken IP rights and impede the operation of the market for inventions will substantially reduce invention and innovation. The use of government prize systems to transfer ownership of private IP to the government would replace allocation by the market for inventions with central planning. The resulting effects on invention and innovation would be devastating for social welfare and economic growth. 


\section{Appendix}

\section{Sources of Data in Table 1}

1. Year of introduction and number of transistors for selected microprocessors (4004, 8080, 8086, Intel286, Intel386, Intel486, Intel Pentium, Intel Pentium II, Intel Pentium

III, Intel Pentium 4, Intel Itanium 2 ), http://www.intel.com/pressroom/kits/events/moores_law_40th/?iid=tech_mooreslaw+bod y presskit, accessed July 10, 2014.

2. Year of introduction and number of transistors for Intel Core 2 Duo, Intel Core 2 Quad, http://download.intel.com/pressroom/kits/IntelProcessorHistory.pdf, accessed July 10, 2014.

3. Year of introduction and number of transistors for Intel Core i3-530, Source: http://www.cpu-world.com/CPUs/Core i3/Intel-Core\%20i3-

530\%20CM80616003180AG\%20(BX8061613530\%20-\%20BXC80616I3530).html, accessed July 10, 2014.

4. Year of introduction and number of transistors for Intel Core i7-377, http://hexus.net/tech/reviews/cpu/37989-intel-core-i7-3770k-22nm-ivy-bridge/, accessed July 10, 2014.

5. Price of the 4004 is $\$ 30$ for 100 to 999 units in 1971 dollars; EDN Staff, "One-Chip CPU Available for Low-Cost Dedicated Computers," January 15, 1972, http://www.edn.com/electronics-products/other/4320004/One-Chip-CPU-available-forlow-cost-dedicated-computers, accessed July 10, 2014.

6. Price of the 8080 is $\$ 360$.

Sources:

http://www.intel.com/pressroom/kits/quickrefyr.htm, http://www.informit.com/articles/article.aspx?p=130978, http://www.scaruffi.com/svhistory/sv/chap86.html, http://en.citizendium.org/wiki/Intel_8080, http://messui.the-chronicles.org/comp/history of microcomputers.pdf, http://www.chips.5u.com/idxhst.html, accessed July 10, 2014.

7. Price of the 8086 is $\$ 360$; http://www.techrepublic.com/blog/classics-rock/intels-8086passes-the-big-3-0/, accessed July 10, 2014.

8. Price of the Intel286 is $\$ 360$, price of the Intel386 is $\$ 299$, price of the Intel486 is $\$ 900$, Intel Pentium II is $\$ 499$, price of the Intel Pentium III is $\$ 239$, and Intel Pentium 4 is $\$ 644$.

"Intel introduces new and updated Pentium III processors based on 0.18-micron technology, code-named Coppermine. The processor incorporates 28 million transistors with 0.18 -micron technology. Speeds and prices in 1000-unit quantities range from 500 $\mathrm{MHz}$ (US\$239) to $733 \mathrm{MHz}$ (US\$776) for desktop versions." "Intel introduces the Pentium 4 processor, at speeds of 1.4 and $1.5 \mathrm{GHz}$.... The processor incorporates 42 
million transistors in a 0.18-micron process. Code-name during development was Willamette. Prices are US\$819 $(1.5 \mathrm{GHz})$ and US\$644 $(1.4 \mathrm{GHz})$ in 1000-unit quantities." Price of the $1.4 \mathrm{GHz}$ Itanium 2 processor is $\$ 1172$ in 1000-unit quantities, http://processortimeline.info/proc1980.htm, accessed July 10, 2014.

9. The price of the Intel Core 2 Duo in 2006 is $\$ 530$, http://www.pcmag.com/article2/0,2817,1989161,00.asp, accessed July 10, 2014. The Intel Core 2 Duo has 291 million transistors, http://download.intel.com/pressroom/kits/IntelProcessorHistory.pdf, accessed July 10, 2014.

10. Intel Core 2 Quad was introduced in 2007 and has 820 million transistors. The price of the Intel Core 2 Quad is $\$ 851$ in quantities of 1,000 . http://www.techspot.com/review/36-intel-core2-quad-q6600/, accessed July 10, 2014.

11. Price of the Intel Core i3-530 Processor in 2010 is $\$ 113$, http://ark.intel.com/products/46472/Intel-Core-i3-530-Processor-4M-Cache-2 93-GHz, accessed July 10, 2014. The Intel Core i3-530 Processor has 382 million transistors; http://www.cpu-world.com/CPUs/Core i3/Intel-Core\%20i3530\%20CM80616003180AG\%20(BX80616I3530\%20-\%20BXC80616I3530).html, accessed July 10, 2014.

12. Price of the Intel Core $17-3770$ in 2012 is $\$ 305$; http://ark.intel.com/products/family/65506/3rd-Generation-Intel-Core-i7-

Processors\#@Desktop, accessed July 10, 2014. The Ivy Bridge microprocessors have 1400 million transistors; http://hexus.net/tech/reviews/cpu/37989-intel-core-i7-3770k22nm-ivy-bridge/, accessed July 10, 2014.

\section{References}

Abramowicz, M., 2003, "Perfecting Patent Prizes," Vanderbilt Law Review, 56, pp. 115236.

Abrams, D. S., U. Akcigit, and J. Popadak, 2013, "Patent Value and Citations: Creative Destruction or Strategic Disruption?," Working Paper, University of Pennsylvania November 5 .

Aizcorbe, A. and S. Kortum, 2005, "Moore's Law and the Semiconductor Industry: A Vintage Model." Scandinavian Journal of Economics, 107 (4), Technology and Change, December, pp. 603-630.

Alchian, A. A., 2008, "Property Rights," The Concise Encyclopedia of Economics, David R. Henderson, ed., Library of Economics and Liberty, Liberty Fund, Inc., available from http://www.econlib.org/library/Enc/PropertyRights.html; accessed 2 March 2013. 
Aldridge, T. T. and D. Audretsch, 2011, "The Bayh-Dole Act and Scientist Entrepreneurship," Research Policy, 40 (8), October, pp. 1058-1067.

Allison, John R., \& Emerson H. Tiller. 2003. The Business Method Patent Myth. 18 (4) Berkeley Technology Law Journal, pp. 987-1084.

Anand, B. N. and T. Khanna, 2000, "The Structure of Licensing Contracts," Journal of Industrial Economics, 48, pp. 103-135.

Anderson, A., 2014, "The Impact of the Affordable Care Act on the Health Care Workforce," Backgrounder No. 2887, March 18, Washington, D.C.: The Heritage Foundation, http://thf_media.s3.amazonaws.com/2014/pdf/BG2887.pdf, Accessed August 9, 2014.

Arora, A., 1996, "Contracting for Tacit Knowledge: The Provision of Technical Services In Technology Licensing Contracts," Journal of Development Economics, 50, pp. 233-256.

Arora, A., and A. Gambardella, 2010, "Ideas for Rent: an Overview of the Market for Technology," Industrial and Corporate Change, 19(3), pp. 775-803.

Arora, A., A. Fosfuri, and A. Gambardella, 2001a, "Markets for Technology and their Implications for Corporate Strategy," Industrial and Corporate Change, 10(2), pp. 419-451.

Arora, A., A. Fosfuri, and A. Gambardella, 2001b, Markets for Technology: The Economics of Innovation and Corporate Strategy, Cambridge, MA: MIT Press.

Arora, A., M. Ceccagnoli, and W. M Cohen, 2007, "Trading Knowledge: An Exploration of Patents Protection and Other Determinants of Market Transactions in Technology and R\&D," Chapter 9 in Naomi R. Lamoreaux and Kenneth L. Sokoloff, eds., Financing Innovation in the United States 1870 to the Present, Cambridge, MA: MIT Press, pp. 365-403.

Arora, A. and R. Merges, 2004, "Specialized Supply Firms, Property Rights and Firm Boundaries," Industrial and Corporate Change, 13, pp. 451-475.

Arqué-Castells, P., 2012, "How Venture Capitalists Spur Invention in Spain: Evidence from Patent Trajectories," Research Policy, 41, pp. 897-912.

Arrow, K. J., 1962, "Economic Welfare and the Allocation of Resources for Invention," in The Rate and Direction of Inventive Activity, Cambridge, MA: National Bureau of Economic Research, pp. 609-626.

Athreye, S. and J. Cantwell, 2007, "Creating competition? Globalisation and the Emergence of New Technology Producers," Research Policy, 36 (2), pp. 209226.

AUTM, U.S. Licensing Activity Survey, FY2012, Association of University Technology Managers, http://www.autm.net/AM/Template.cfm?Section=FY2012_Licensing_Activity_S urvey \&Template $=/ \mathrm{CM} /$ ContentDisplay.cfm $\&$ ContentID $=11435$, Accessed April 4, 2014. 
Barinka, A., 2014, "IBM Wins Most U.S. Patents for 21st Year in a Row," Bloomberg Technology, January 14, http://www.bloomberg.com/news/2014-01-14/ibm-winsmost-u-s-patents-for-21st-year-in-a-row.html, Accessed January 25, 2014.

Barry, J., 2007, "When Second Comes First: Correcting Patent's Poor Secondary Incentives Through an Optional Patent Purchase System," Wisconsin Law Review, 2007, pp. 585-.

Barzel, Y., 1968, "Optimal Timing of Innovations," Review of Economics \& Statistics, 50, 3, August, pp. 348-355.

Baumol, W. J. and R. D. Willig, 1981, "Fixed Costs, Sunk Costs, Entry Barriers, and Sustainability of Monopoly," Quarterly Journal of Economics, 96 (3), August, pp. 405-431.

Baumol, W. J., J. C. Panzar, and R. D. Willig, 1988, Contestable Markets and the Theory of Industry Structure, New York: Harcourt Brace Jovanovich.

Baye, M. R., and H. C. Hoppe, 2003, "The Strategic Equivalence of Rent-Seeking, Innovation, and Patent-Race Games," Games and Economic Behavior, 44, pp. 217-226.

Bayh, B., J. P. Allen, and H. W. Bremer, 2009, "Universities, Inventors, and the BayhDole Act," Life Sciences Law \& Industry Report, 3, 24, December 18, pp. 1-5.

Becker, G. S., 1962, "Investment in Human Capital: A Theoretical Analysis," Journal of Political Economy, 70, 5, Part 2: Investment in Human Beings, October, pp. 9-49.

Bessen, J. and M. J. Meurer, 2008, Patent Failure: How Judges, Bureaucrats and Lawyers put Innovations at Risk. Princeton, NJ: Princeton University Press.

Biglaiser, G., 1993, "Middlemen as Experts," Rand Journal of Economics, 24 (2), Summer, pp. 212-223.

Biglaiser, G. and J. W. Friedman, 1994, "Middlemen as Guarantors of Quality," International Journal of Industrial Organization, 12, 4, December, pp. 509-531,

Biglaiser, G. and J. W. Friedman, 1999, "Adverse Selection with Competitive Inspection," Journal of Economics \& Management Strategy, 8: pp. 1-32.

Boldrin, M. and D. K. Levine, 2008, Against Intellectual Monopoly, Cambridge: Cambridge University Press.

Boldrin, M. and D. K. Levine, 2013, "The Case against Patents," Journal of Economic Perspectives, 27, 1, Winter, pp. 3-22.

Browning, E. K., 1976, "The Marginal Cost of Public Funds," Journal of Political Economy, 84 (2), pp. 283-298.

Brunt, L., J. Lerner, and T. Nicholas, 2012, "Inducement Prizes and Innovation," Journal of Industrial Economics 45(4), pp. 657-696.

Burk, D. L. and M. A. Lemley, 2009, Patent Crisis and How the Courts Can Solve It. Chicago: University of Chicago Press.

Calandrillo, S. P., 1998, “An Economic Analysis of Intellectual Property Rights: Justifications and Problems of Exclusive Rights, Incentives to Generate 
Information, and the Alternative of a Government-Run Reward System, 9 FORDHAM INTELL. PROP. MEDIA \& ENT. L.J. 301-.

Chamberlin, E., 1933, The Theory of Monopolistic Competition, Cambridge, MA: Harvard University Press.

Chari, V.V., M. Golosov, and A. Tsyvinski, 2012, "Prizes and Patents: Using Market Signals to Provide Incentives for Innovations," Journal of Economic Theory, 147, pp. 781-801.

Che, Yeon-Koo, and Ian Gale. 2003. "Optimal Design of Research Contests." American Economic Review 93(3): 646-671.

Coase, R., 1946, “The Marginal Cost Controversy,” Economica, New Series, 13 (51), August, pp. 169-182.

Coase, R., 1947, "The Marginal Cost Controversy: Some Further Comments," Economica, New Series, 14 (54), May, pp. 150-153.

Corrado, C., C. Hulten, and D. Sichel, 2009, "Intangible Capital and U.S. Economic Growth," Review of Income and Wealth, 55, pp. 661-685.

Cournot, A., 1838, Recherches sur les principes mathématiques de la théorie des richesses, Paris: L. Hachette.

Daily, J. E. and F. S. Kieff, 2013, "Anything Under The Sun Made By Humans: Patent Law Doctrines As Endogenous Institutions For Commercializing Innovation," Emory Law Journal, 62, pp. 967-981.

Dasgupta, P., Stiglitz, J., 1980, "Uncertainty, Industrial Structure, and the Speed of R\&D," Bell Journal of Economics, 11, pp. 1-28.

Diewert, W. E., 1981, “The Measurement of Deadweight Loss Revisited," Econometrica, 49 (5), September, pp. 1225-1244,

de Laat, E. A. A., 1996, "Patents or Prizes: Monopolistic R\&D and Asymmetric Information," International Journal of Industrial Organization, 15, pp. 369-390.

Demsetz, H., 1968, "Why Regulate Utilities?," Journal of Law \& Economics, 11, pp. 55-.

Demsetz, H., 1969, "Information and Efficiency: Another Viewpoint," Journal of Law \& Economics, 12, pp. 1-22.

Dore, M. H. I. and M. C. Kaser, 1984, "The Millions of Equations Debate: Seventy Years After Barone," Atlantic Economic Journal, 12 (3), September, pp 30-44.

Duffy, J. F., 2004, “The Marginal Cost Controversy in Intellectual Property," University of Chicago Law Review, 71 (1), Winter, pp. 37-56.

Dupuit, A. J. É. J., 1844, "De la mesure de l'utilité des travaux publics," Annales des ponts et chaussées, Second series, 8. Translated by R.H. Barback as On the Measurement of the Utility of Public Works, International Economic Papers, 1952, 2, 83-110, reprinted in K. J. Arrow and T. Scitovsky, eds., 1969, Readings in Welfare Economics, Homewood, IL: Irwin, pp. 255-283.

Ekelund, R.B., 1968, "Jules Dupuit and the Early Theory of Marginal Cost Pricing," Journal of Political Economy, 76 (3), May-June, pp. 462-471. 
Epstein, R. A., 2010, “The Disintegration of Intellectual Property - A Classical Liberal Response to a Premature Obituary," Stanford University Law Review, 62, January, pp. 455-522.

Epstein, R. J. and P. Malherbe, 2011, "Reasonable Royalty Patent Infringement Damages after UNILOC," AIPLA Quarterly Journal, 39, pp. 3-34.

Erkal, N. and S. Scotchmer, 2009, Scarcity of Ideas and R\&D Options: Use It, Lose It or Bank It, National Bureau of Economic Research, Working Paper 14940, Cambridge, MA.

Feldstein, M., 1999, "Tax Avoidance and the Deadweight Loss of the Income Tax," Review of Economics and Statistics, 81 (4), November, pp. 674-680.

Federal Trade Commission, 2011, The Evolving IP Marketplace: Aligning Patent Notice and Remedies with Competition, Washington, D.C., March.

Fisher, I., 1906, The Nature of Capital and Income, New York: The Macmillan Company.

Fisher, I., 1907, Rate of Interest: Its Nature, Determination and Relation to Economic Phenomena, New York: The Macmillan Company.

Fisher, I., 1930, The Theory of Interest: As Determined by Impatience to Spend Income and Opportunity to Invest It, New York: The Macmillan Company.

Fullerton, R. L. and R. P. McAfee, 1999, “Auctioning Entry into Tournaments,” Journal of Political Economy, 107, pp. 573-605.

Gallini, N. and S. Scotchmer, 2002, "Intellectual Property: When Is It the Best Incentive System?" Adam B. Jaffe, Josh Lerner, and Scott Stern, eds., Innovation Policy and the Economy, v. 2, Cambridge, MA: MIT Press, pp. 51-77, http://www.nber.org/chapters/c10785, accessed August 3, 2014.

Galasso, A., M. Schankerman, and C. J. Serrano, 2013, "Trading and Enforcing Patent Rights," RAND Journal of Economics, 44, 2, Summer, pp. 275-312.

Gambardella, A., P. Giuri, and A. Luzzi, 2007, "The Market for Patents in Europe," Research Policy, 36, pp. 1163-1183.

Gans, J. S. and S. Stern, 2010, "Is There a Market for Ideas?," Industrial and Corporate Change, 19(3), pp. 805-837.

Gans, J. S., D. H. Hsu and S. Stern, 2008, “The Impact of Uncertain Intellectual Property Rights on the Market for Ideas: Evidence for Patent Grant Delays," Management Science, 54, 5, pp. 982-997.

Giuri, P., M. Mariani, S. Brusoni, , G. Crespi, D. Francoz, A. Gambardella, W. GarciaFontes, A. Geuna, R. Gonzales, D. Harhoff, K. Hoisl, C. Lebas, A. Luzzi, L. Magazzini, L. Nesta, O. Nomaler, N. Palomeras, P. Patel, M. Romanelli, and B. Verspagen, 2007. "Inventors and Invention Processes in Europe: Results from the PatVal-EU Survey," Research Policy, October, 36 (8), pp.

Graham, S. J. H., R. P. Merges, P. Samuelson, and T. Sichelman, 2009, "High Technology Entrepreneurs and the Patent System: Results of the 2008 Berkeley 
Patent Survey," Berkeley Technology Law Journal, 24, 4, Fall, Article 1, pp. 1255-1327, http://scholarship.law.berkeley.edu/btlj/vol24/iss4/1, accessed April 5, 2014.

Griliches, Z., 1979, "Issues in Assessing the Contribution of Research and Development to Productivity Growth," Bell Journal of Economics, 10, 1, Spring, pp. 92-116.

Grimaldi, R., M. Kenney, D. S. Siegel and M. Wright, eds., 2011, Special Issue: 30 Years After Bayh-Dole: Reassessing Academic Entrepreneurship, Research Policy, 40 (8), October, pp. 1045-1057.

Hagiu, Andrei and David B. Yoffie, 2013, "The New Patent Intermediaries: Platforms, Defensive Aggregators, and Super-Aggregators," Journal of Economic Perspectives, Volume 27, Number 1, Winter, pp. 45-66.

Hall, B. H., 1993, "The Stock Market Value of R\&D Investment during the 1980s," American Economic Review, 83, pp. 259-64.

Hall, B. H., G. Thoma and S. Torrisi, 2007, "The Market Value of Patents and R\&D: Evidence from European Firms," Working Paper, University Of California, Berkeley.

Harberger, A. C., 1964, "The Measurement of Waste," American Economic Review, 54, pp. 58-76.

Harberger, A. C., 1971, "Three Basic Postulates For Applied Welfare Economics: An Interpretive Essay," Journal of Economic Literature, 9, pp. 785-797.

Hayek, F. A., 1945, "The Use of Knowledge in Society," American Economic Review, 35 (4), September, pp. 519-530.

Hayek, F. A., 1975, “The Pretence of Knowledge," Swedish Journal of Economics, 77, 4, December, pp. 433-442.

Hopenhayn, H., G. Llobet, and M. Mitchell, 2006, "Rewarding Sequential Innovators: Prizes, Patents, and Buyouts," Journal of Political Economy, 114, pp. 1041-1068.

Hotelling, H., 1938, "The General Welfare in Relation to the Problems of Taxation and of Railway and Utility Rates," Econometrica, 6, July, pp. 242-269.

Intel Corporation, 2005, Excerpts from A Conversation with Gordon Moore: Moore's Law, Video transcript, http://web.eng.fiu.edu/npala/eee6397ex/gordon_moore_1965_article.pdf, Accessed July 1, 2014.

Jaffe, A. B. and J. Lerner, 2004, Innovation and its Discontents: How our Broken Patent System is Endangering Innovation and Progress, and What to do About It, Princeton, NJ: Princeton University Press.

Jensen, M. and W. Meckling, 1976, "Theory of the Firm: Managerial Behavior, Agency Costs and Ownership Structure," Journal of Financial Economics, 3, pp. 305360 .

Jensen, P. H., A. Palangkaraya, and E. Webster, 2006, "Disharmony in International Patent Office Decisions," Federal Circuit Bar Journal, 15, pp. 679-704. 
Judd, K. L., 1987, “The Welfare Cost of Factor Taxation in a Perfect-Foresight Model," Journal of Political Economy, 95 (4), pp. 675-709.

Kapczynski, A., 2012, "The Cost of Price: Why and How to Get Beyond Intellectual Property Internalism," UCLA Law Review, 59, pp. 970-1027.

Kapczynski, A. and T. Syed, 2013, "The Continuum of Excludability and the Limits of Patents, Yale Law Journal, 122, pp. 1900-1963.

Katznelson, R. D., 2007, "Bad Science in Search of "Bad" Patents," Federal Circuit Bar Journal, 17 (1), pp. 1-30.

Khan, B. Z., 2005, The Democratization of Invention: Patents and Copyrights in American Economic Development, 1790-1920, Cambridge, MA: NBER.

Khan, B. Z., 2011, "Premium Inventions: Patents and Prizes as Incentive Mechanisms in Britain and the United States, 1750-1930" in Dora L. Costa and Naomi R. Lamoreaux (eds), Understanding Long-Run Economic Growth: Geography, Institutions, and the Knowledge Economy, NBER and University of Chicago, pp. 205-234.

Khan, B. Z., 2013a, "Going for Gold: Industrial Fairs and Innovation in the NineteenthCentury United States," Revue Economique, Special Issue on Innovation without Patents, 64 (1), pp. 89-114.

Khan, B. Z., 2013b, "Selling Ideas: An International Perspective on Patenting and Markets for Technological Innovations, 1790-1930," Business History Review, 87, Spring, pp. 39-68.

Khan, B. Z., 2014a, "Trolls and Other Patent Inventions: Economic History and The Patent Controversy in the Twenty-First Century," Working Paper, Department of Economics, Bowdoin College and NBER.

Khan, B. Z., 2014b, "The Social Consequences of Patent Institutions and Prizes in Technology Markets," in D. Halbert and W. Gallagher (eds) Interdisciplinary Perspectives on Intellectual Property Law (forthcoming).

Khan, B. Z., 2014c, "Of Time and Space: Technological Spillovers among Patents and Unpatented Innovations in Early U.S. Industrialization" Department of Economics, Bowdoin College and NBER.

Khan, B. Z. and K. L. Sokoloff, 2001, "History Lessons: The Early Development of Intellectual Property Institutions in the United States," Journal of Economic Perspectives, Summer, pp.

Kamiyama, Shigeki/Jerry Sheehan/Catalina Martinez, 2006, "Valuation and Exploitation of Intellectual Property," STI Working Paper 2006/5. Paris: OECD.

Kieff, F. S., 2001, "Property Rights and Property Rules for Commercializing Inventions," Minnesota Law Review, 85, pp. 697-754.

Kieff, F. S., 2003, "The Case for Registering Patents and the Law and Economics of Present Patent-Obtaining Rules," Boston College Law Review, 45, pp. 55-124. 
Kitch, E. W., 1977, "The Nature and Function of the Patent System," Journal of Law \& Economics, 20, pp. 265-267.

Kitch, E. W., 2000, "Elementary and Persistent Errors in the Economic Analysis of Intellectual Property," Vanderbilt Law Review, 53, pp. 1727-1741.

Knight, F. H., 1921, Risk, Uncertainty and Profit, Boston: Houghton Mifflin.

Kornai, J. and Th. Lipták, 1965, "Two-Level Planning," Econometrica, 33, 1, January, pp. 141-169.

Kremer, M., 1998, "Patent Buyouts: A Mechanism for Encouraging Innovation," Quarterly Journal of Economics, 113, pp. 1137-1167.

Kremer, M. and H. Williams. 2010. "Incentivizing Innovation: Adding to the Toolkit." Innovation Policy and the Economy, 1, pp. 1-17.

Lamoreaux, N. R. and K. L. Sokoloff, 2003, "Intermediaries in the U.S. Market for Technology, 1870-1920," in Stanley L. Engerman, Philip T. Hoffman, JeanLaurent Rosenthal and Kenneth L. Sokoloff, eds., Finance, Intermediaries, and Economic Development, pp. 209-246.

Lange, O., 1943, "A Note on Innovations," Review of Economics and Statistics, 25, 1, February, pp. 19-25

Lange, O., 1936-1937,."On the Economic Theory of Socialism," Review of Economic Studies, IV, Nos. 1 and 2, pp.

Lange, O., 1945-1946, "The Scope and Method of Economics," Review of Economic Studies, 13, (1), pp. 19-32.

Lazear, E. P. and S. Rosen, 1981, "Rank-order tournaments as optimum labor contracts," Journal of Political Economy, 89(5), pp. 841-864.

Lemley, Mark A., 2001, "Rational Ignorance at the Patent Office," Northwestern University Law Review, 95, pp. 1495-1529.

Lemley, M. A. and K. A. Moore, 2004, "Ending Abuse of Patent Continuations," Boston University Law Review, 84, pp. 63-124.

Lemley, M. A. and C. Shapiro, 2005, "Probabilistic Patents," Journal of Economic Perspectives, 19, 2, Spring, pp. 75-98.

Levmore, S., 2013, "The Impending iPrize Revolution in Intellectual Property Law," 93 BOSTON U.L. REV. 139-.

Lerner, A. P., 1977, “Marginal Cost Pricing in the 1930's," American Economic Review, 67 (1), Papers and Proceedings of the Eighty-ninth Annual Meeting of the American Economic Assocation, February, pp. 235-243.

Lichtman, D. G., 1997, "Pricing Prozac: Why the Government Should Subsidize the Purchase of Patented Pharmaceuticals, 11 HARV. J.L. \& TECH. 123-.

Llobet, G. and J. Padilla, 2014, "The Optimal Scope of the Royalty Base in Patent Licensing," Working Paper, CEMFI, Madrid.

Love, J. and T. Hubbard, 2007, "The Big Idea: Prizes to Stimulate R\&D for New Medicines," Chicago-Kent Law Review, 82, pp. 1519-1554. 
Machlup, F., 1962, The Production and Distribution of Knowledge in the United States, Vol. 278, Princeton: Princeton University Press.

Machlup, F. and E. Penrose, 1950, "The Patent Controversy in the Nineteenth Century," Journal of Economic History, 10, pp. 1-29.

Maggs, P. B., 1990, "Restructuring of the Soviet Law in Inventions," Columbia Journal of Transnational Law, 28 , pp. 277-289.

Mann, W., 2014, "Creditor Rights and Innovation: Evidence from Patent Collateral," Wharton Working Paper, May 1, http://fnce.wharton.upenn.edu/pro le/1033/.

Martinez, C. and D. Guellec, 2004, "Overview of Recent Changes and Comparison of Patent Regimes in the United States, Japan and Europe", in Patents, Innovations and Economic Performance: OECD Conference Proceedings, pp. 127-145.

McCaffrey, C., 2011, "The Virtues of Virtual Marking in Patent Reform," Northwestern University Law Review, 105 (1), pp. 367-400.

McDonough, J. F., 2006, "The Myth of the Patent Troll: An Alternative View of the Function of Patent Dealers in an Idea Economy," Emory Law Journal, 56, pp. $189-228$.

McGrattan, E. R., and E. C. Prescott, 2009, "Openness, Technology Capital, and Development," Journal of Economic Theory, 144 (6), pp. 2454-2476.

Merges, Robert P., 1999, "As Many as Six Impossible Patent before Breakfast: Property Rights for Business Concepts and Patent System Reform," Berkeley Technology Law Journal, 14, pp. 577-616.

Mill, J. S., 1848, Principles of Political Economy: With Some of Their Applications to Social Philosophy, 1st ed., ed. William James Ashley (London: Longmans, Green and Co., 1909, 7th ed.). 5/27/2014, http://oll.libertyfund.org/titles/101, Accessed May 27, 2014.

Moldovanu, B. and A. Sela, 2001, "The Optimal Allocation of Prizes in Contests," American Economic Review, 91 (3), June, pp. 542-558.

Moore, G. E., 1965, "Cramming More Components Onto Integrated Circuits," Electronics Magazine, 38, 8, April 19, pp. 114-117.

Moore, G. E., 1995, "Lithography and the Future of Moore's Law," Optical/Laser Microlithography VIII: Proceedings of the SPE, 2440, February 20, pp. 2-17.

Moore, G. E., 1998, "The Role of Fairchild in Silicon Technology in the Early Days of 'Silicon Valley'," Proceedings of the IEEE, 86, 1, January, pp. 53-62.

Moser, P. and T. Nicholas, 2013, "Prizes, Publicity, And Patents: Non-Monetary Awards As A Mechanism To Encourage Innovation." Journal of Industrial Economics 61(3), pp. 763-788.

Munari, F. and R. Oriani, eds., 2011, The Economic Valuation of Patents: Methods and Applications, Cheltenham, UK: Edward Elgar Publishing.

Murphy, W. J., J. L. Orcutt, and P. C. Remus, 2012 , Patent Valuation: Improving Decision Making through Analysis, New York: John Wiley \& Sons. 
Murray, F., S. Stern, G. Campbell, and A. MacCormack. 2012. "Grand Innovation Prizes: A Theoretical, Normative, and Empirical Evaluation." Research Policy 41(10): 1779-1792.

Myers, S. C., 1977, "Determinants of Corporate Borrowing," Journal of Financial Economics, 5 (2), November, pp. 147-175.

Myers, S. C., 1999, "Financial Architecture," European Financial Management, 5, 2, pp. 133-141.

Myers, S. C., 2000, “Outside Equity,” Journal of Finance, 55, 3, June, pp. 1005-1037.

Myrvold, N., 2010, "Funding Eureka! The Big Idea," Harvard Business Review, March, pp. 1-10.

Nalebuff, B. J. and J. E. Stiglitz, 1983, "Prizes and Incentives: Towards a General Theory of Compensation and Competition," Bell Journal of Economics, Spring, 14(1), pp. $21-43$.

National Science Board, 2014, Science and Engineering Indicators 2014, Washington, D.C.: National Science Foundation, http://www.nsf.gov/statistics/seind14/content/etc/nsb1401.pdf, Accessed June 15, 2014.

Nordhaus, W. D., 1969, Invention, Growth, and Welfare: A Theoretical Treatment of Technological Change, Cambridge, MA: MIT Press.

Nordhaus, W. D., 1972, "The Optimum Life of a Patent: Reply," American Economic Review, 62, pp. 428-431.

Pakes, A., 1986, "Patents as Options: Some Estimates of the Value of Holding European Patent Stocks," Econometrica, 54 (4), pp. 755-784.

PatVal-EU Project, 2005, Coordinator: Alfonso Gambardella, Study on Evaluating the Knowledge Economy - What are Patents Actually Worth? The Value of Patents for Today's Economy and Society. Final Report for Lot 1. Pisa: Laboratory of Economics and Management (LEM), Sant' Anna School of Advanced Studies.

PatVal-EU Project, 2006, Alfonso Gambardella, Paola Giuri, Myriam Mariani, Study on Evaluating the Knowledge Economy - What are Patents Actually Worth? The Value of Patents for Today's Economy and Society. Final Report for Lot 2. Pisa: Laboratory of Economics and Management (LEM), Sant' Anna School of Advanced

Studies. http://ec.europa.eu/internal_market/indprop/docs/patent/studies/final_report_lot2 en.pdf

Pigou, A. C., 1947, A Study of Public Finance, $3^{\text {rd }}$ ed., London: Macmillan.

Poblete, J. and D. F. Spulber, 2012, "The Form of Incentive Contracts: Agency with Moral Hazard, Risk Neutrality, and Limited Liability," Rand Journal of Economics, 43, 2, Summer, pp. 215-234. 
Poblete, J. and D. F. Spulber, 2014, "Managing Innovation: Optimal Agency Contracts for Delegated R\&D, Kellogg School of Management Working Paper, Evanston, IL.

Polanvyi, M., 1944, "Patent Reform," Review of Economic Studies, 11, 2, Summer, pp. 61-76.

Reinganum, J. F., 1981, “Dynamic Games of Innovation,” Journal of Economic Theory, 25, pp. 1-41.

Reinganum, J. F., 1982, "A Dynamic Game of R and D: Patent Protection and Competitive Behavior," Econometrica, 50, pp. 671-688.

Reinganum, J. F., 1989, "The Timing of Innovation: Research, Development, and Diffusion,” in R. Schmalensee and R. D. Willig, eds., Handbook of Industrial Organization, v. 1, New York: Elsevier Science Publishers, pp. 849-908.

Rich, Giles S., 1972, "Laying the Ghost of the 'Invention' Requirement," American Intellectual Property Law Quarterly Journal, 1 (1), pp. 26-45.

Riis, C., 2010, "Efficient Contests," Journal of Economics \& Management Strategy, 19 (3), Fall, pp.

Robbins, C. A.,, 2009, "Measuring Payments for the Supply and Use of Intellectual Property," in Marshall Reinsdorf and Matthew J. Slaughter, eds., International Trade in Services and Intangibles in the Era of Globalization, National Bureau of Economic Research, Chicago: University of Chicago Press, pp. $139-171$.

Roin, B. N., 2014, "Intellectual Property versus Prizes: Reframing the Debate," University of Chicago Law Review, 81, forthcoming.

Schaller, R. A., 1997, “Moore's Law: Past, Present, and Future,” IEEE Spectrum, June, pp. 53-59.

Schankerman, M. and A. Pakes, 1986, "Estimates of the Value of Patent Rights in European Countries during the Post-1950 Period," Economic Journal, 96, pp. 1052-1076.

Scherer, F. M., 1972, "Nordhaus' Theory of Optimal Patent Life: A Geometric Reinterpretation," American Economic Review, 62, pp. 422-427.

Shleifer, A., 1985, "A Theory of Yardstick Competition," Rand Journal of Economics, Autumn, 16(3), pp. 319-27.

Serrano, C. J., 2010, "The Dynamics of the Transfer and Renewal of Patents," Rand Journal of Economics, 41, 4, Winter, pp. 686-708.

Shavell, S. and T. van Ypersele, 2001, "Rewards versus Intellectual Property Rights, Journal of Law \& Economics, 44, 2, pp. 525-547.

Siegel, D. S., Veugelers, R., and M. Wright, 2007, "Technology Transfer Offices and Commercialization of University Intellectual Property: Performance and Policy Implications," Oxford Review of Economic Policy 23, 4, pp. 640-660.

Smith, H. E., 2002, "Exclusion versus Governance: Two Strategies for Delineating Property Rights," Journal of Legal Studies, 31, pp. S453-S487. 
Smith, H. E., 2007, "Intellectual Property as Property: Delineating Entitlements in Information," Yale Law Journal, 116, 8, June, pp. 1742-1822.

Smith, H. E., 2009, "Institutions and Indirectness in Intellectual Property," University of Pennsylvania Law Review, 157, 6, June, Symposium: The Foundations of Intellectual Property Reform, pp. 2083-2133.

Spulber, D. F., 1989, Regulation and Markets, Cambridge, MA: MIT Press.

Spulber, D. F., 1995, "Deregulating Telecommunications," Yale Journal on Regulation, 12(1), pp. 25-67.

Spulber, D. F., 1996, "Market Microstructure and Intermediation," Journal of Economic Perspectives, 10, 3, Summer, pp. 135-152.

Spulber, D. F., 1999, Market Microstructure: Intermediaries and the Theory of the Firm, Cambridge: Cambridge University Press.

Spulber, D. F., 2008, "Innovation and International Trade in Technology," Journal of Economic Theory, 138, January, pp. 1-20.

Spulber, D. F., 2009a, The Theory of the Firm: Microeconomics with Endogenous Entrepreneurs, Firms, Markets, and Organizations, Cambridge: Cambridge University Press.

Spulber, D. F., 2009b, "Discovering the Role of the Firm: The Separation Criterion and Corporate Law," Berkeley Business Law Journal, 6 (2), Spring, pp. 298-347.

Spulber, D. F., 2010, "The Quality of Innovation and the Extent of the Market," Journal of International Economics, 80, pp. 260-270.

Spulber, D. F., 2011, "Should Business Method Inventions Be Patentable?," Journal of Legal Analysis, 3 (1), pp. 265-340.

Spulber, D. F., 2012, “Tacit Knowledge with Innovative Entrepreneurship," International Journal of Industrial Organization, 30, 6, November, pp. 641-653

Spulber, D. F., 2013a, "Competing Inventors and the Incentive to Invent," Industrial and Corporate Change, 22, 1, February, pp. 33-72.

Spulber, D. F., 2013b, "How Do Competitive Pressures Affect Incentives to Innovate when there is a Market for Inventions?," Journal of Political Economy, 121 (6), December, pp. 1007-1054.

Spulber, D. F., 2013c, "Innovation Economics: The Interplay among Technology Standards, Competitive Conduct, and Economic Performance," Journal of Competition Law \& Economics, 9, 4, pp. 777-825.

Spulber, D. F., 2014, The Innovative Entrepreneur, New York: Cambridge University Press.

Stiglitz, J. E., 2006, “A Better Way to Crack It,” New Scientist, 191, 2569, September, p. 20.

Stiglitz, J. E., 2008, "Economic Foundations of Intellectual Property Rights," Duke Law Journal, 57 (6), April, pp. 1693-1724. 
Stiglitz, J. E., 2014, "Intellectual Property Rights, the Pool of Knowledge, and Innovation," NBER working paper 20014, March 2014, available at http://www.nber.org/papers/w20014.pdf?new_window=1, Accessed June 21, 2014.

Taylor, C. R., 1995, "Digging for Golden Carrots: An Analysis of Research Tournaments," American Economic Review, Vol. 85, No. 4, September, pp. $872-$ 890.

Taylor, F. M., 1929, "The Guidance of Production in the Socialist State," American Economic Review, Vol. 19, No. i, pp.

Teece, D. J., 1986, "Profiting from Technological Innovation: Implications for Integration, Collaboration, Licensing, and Public Policy," Research Policy, 15, 6, pp. 285-305.

Teece, D. J., 2006, "Reflections on 'Profiting from Innovation," Research Policy, 35, pp. 1131-1146.

Telser, L. G., 1960, “Why Should Manufacturers Want Fair Trade?”, Journal of Law and Economics, Vol. 3 (Oct., 1960), pp. 86-105

Thomas, J. R., 2002, "The Responsibility of the Rulemaker: Comparative Approaches to Patent Administration Reform," Berkeley Technology Law Journal, 17, pp. 727762.

Troy, I. and R. Werle, 2008, "Uncertainty and the Market for Patents," MPIfG Working Paper. Cologne.

U.S. House of Representatives, 2013, Committee on Ways and Means, Committee on Education and the Workforce, and Committee on Energy and Commerce, "Obamacare Burden Tracker," http://waysandmeans.house.gov/uploadedfiles/aca_burden_tracker_final_5_6_13. pdf, Accessed August 9, 2014.

Wei, M. 2007, "Should Prizes Replace Patents? A Critique of the Medical Innovation Prize Act of 2005, Boston University Journal of Science and Technology, 13, pp. 25-45.

Weyl, E. G., 2014, "A Short Summary of Price Theory," under preparation for the Journal of Economic Literature, Working Paper, May, Department of Economics, University of Chicago.

Weyl, E. G. and M. Fabinger, 2013, "Pass-Through as an Economic Tool: Principles of Incidence under Imperfect Competition," Journal of Political Economy, Vol. 121, No. 3, June, pp. 528-583.

Weyl, E. G. and J. Tirole, 2013, "Market Power Screens Willingness-to-Pay," Quarterly Journal of Economics, 127 (4), pp. 1971-2003.

Wildasin, David E., 1984, "On Public Good Provision with Distortionary Taxation," Economic Inquiry, 22(2), April, pp. 227-243. 
World Intellectual Property Organization, 2011, World Intellectual Property Report: The Changing Face of Innovation, Geneva, Switzerland.

Wright, B. D., 1983, "The Economics of Invention Incentives: Patents, Prizes, and Research Contracts," American Economic Review, 73, 4, September, pp. 691-707.

Wright, B. D., K. Drivas, Z. Lei, and S. A. Merrill, 2014, "Technology Transfer: Industry-funded Academic Inventions Boost Innovation," Nature 507, no. 7492, pp. 297-299.

Yanagisawa, T. and D. Guellec, 2009, “The Emerging Patent Marketplace," OECD Science, Technology and Industry Working Papers, 2009/09, OECD Publishing, http://dx.doi.org/10.1787/218413152254, Accessed January 25, 2014.

Zeckhauser, R., 1996, "The Challenge of Contracting for Technological Information," Proceedings of the National Academy of Sciences, 93, November, pp. 1274312748.

Ziedonis, A. A., 2007, "Real Options in Technology Licensing," Management Science, 53 (10), October, pp. 1618-1633. 